\title{
Genes and genome editing tools for breeding desirable phenotypes in ornamentals
}

\author{
A. Giovannini ${ }^{1} \cdot$ M. Laura ${ }^{1}$ - B. Nesi ${ }^{2} \cdot$ M. Savona ${ }^{1} \cdot$ T. Cardi $^{3}$ (1)
}

Received: 2 August 2020 / Accepted: 27 October 2020 / Published online: 3 January 2021

(c) Springer-Verlag GmbH Germany, part of Springer Nature 2021

\begin{abstract}
Key message We review the main genes underlying commercial traits in cut flower species and critically discuss the possibility to apply genome editing approaches to produce novel variation and phenotypes.

Abstract Promoting flowering and flower longevity as well as creating novelty in flower structure, colour range and fragrances are major objectives of ornamental plant breeding. The novel genome editing techniques add new possibilities to study gene function and breed new varieties. The implementation of such techniques, however, relies on detailed information about structure and function of genomes and genes. Moreover, improved protocols for efficient delivery of editing reagents are required. Recent results of the application of genome editing techniques to elite ornamental crops are discussed in this review. Enabling technologies and genomic resources are reviewed in relation to the implementation of such approaches. Availability of the main gene sequences, underlying commercial traits and in vitro transformation protocols are provided for the world's best-selling cut flowers, namely rose, lily, chrysanthemum, lisianthus, tulip, gerbera, freesia, alstroemeria, carnation and hydrangea. Results obtained so far are described and their implications for the improvement of flowering, flower architecture, colour, scent and shelf-life are discussed.
\end{abstract}

Keywords Ornamental crops $\cdot$ Genome editing $\cdot$ Plant regeneration $\cdot$ Plant transformation $\cdot$ Floriculture

\begin{abstract}
Abbreviations
DSB

NHEJ

HDR
\end{abstract}

$\begin{array}{ll}\text { CRISPR/Cas9 } & \begin{array}{l}\text { Clustered regularly interspaced short } \\ \text { palindromic repeats/CRISPR-associated } 9\end{array} \\ \text { endonuclease } & \text { Cas9-sgRNA ribonucleoprotein }\end{array}$

\section{Introduction}

"If you want to feed someone, give them some rice, if you want to give them a reason for living, give them a flower" (Kingsbury 2009). This Chinese proverb synthesizes well our relationship with ornamental plants. The latter are grown

1 CREA Research Centre for Vegetable and Ornamental Crops (CREA OF), Corso degli Inglesi 508, 18038 Sanremo, Italy

2 CREA Research Centre for Vegetable and Ornamental Crops (CREA OF), Via dei Fiori 8, 51017 Pescia, Italy

3 CREA Research Centre for Vegetable and Ornamental Crops (CREA OF), Via Cavalleggeri 25, 84098 Pontecagnano Faiano, Italy 
for decorative purposes in gardens and landscape design projects, as houseplants, for cut flowers and specimen display. Floriculture represents an economically important sector of horticulture. Ornamental plants production is related to different characters and markets: cut flowers and ornamental foliage, indoor potted plants, balcony plants, outdoor plants, bulbous and nursery plants. In 2018, the value of global floriculture production amounted to 43.23 billion U.S. Dollar (bn US\$), with Europe accounting for the largest market share in the global floriculture market (40.3\%). Cut flowers, used mainly for decoration purposes, but increasingly also in perfume and fragrance industry and in medicine, were valued at 6.98 bn US\$ and projected to increase to 11.68 bn US $\$$ by 2027 , equivalent to about $16 \%$ of total market value. Top ten major flower producing countries in the world during 2018 were: The Netherlands (52\% of global market share), Columbia (15\%), Ecuador (9\%), Kenya (7\%), Belgium (3\%), Ethiopia (2\%), Malaysia, Italy, Germany and Israel (1\% each). Before the COVID-19 pandemic, the cut flower market was expected to show a compound annual growth rate of 6.0\% during the 2017-2027 period (Floriculture Market: Global Industry Insights, Trends, Outlook, and Opportunity Analysis, 2019-2027, Coherent Market Insights, https://www.coherentmarketinsights.com; Floriculture-world-wide production, trade, consumption pattern, market opportunities and challenges, https://medium.com/@ preetisharma_51610/).

Due to the continuous increasing demand, floriculture industry requires new and more varieties with elite characters: the promotion of flowering, by both increasing the number of flowers and modulating flowering time, and flower longevity as well as the creation of novelty in flower structure, colour range and fragrances, are major objectives of ornamental plant breeding. Among traits, the colour of flowers primarily influences their commercial value. Ornamental species show specific colours: for example, blue chrysanthemums, yellow cyclamens, red iris and blue roses do not exist in nature, since they do not have the pathways leading to the relevant pigments (Tanaka et al. 2009).

The development of new and efficient breeding approaches benefits from the information concerning physiological and genetic mechanisms underpinning target traits. Although classical breeding strategies (such as intra and interspecific hybridization, mutagenesis, polyploidization, double haploid induction, etc.) have been extensively employed to develop new plant lines, limitations and drawbacks are still evident. The limited gene pool available for new traits in some species, the high heterozygosity in many valuable floricultural crops (e.g. rose, chrysanthemum and carnation), the huge genome size (chrysanthemum, lilium) and chromosome number (hibiscus), the long lifecycle (anthurium), the self-sterility and inability to produce seeds of most cultivars (carnation, chrysanthemum, rose), strongly restrict the applicability of conventional breeding approaches. As far as mutation breeding is concerned, the main problems are the randomness of mutations, which often requires a huge amount of work to sort out the useful mutation, as well as the induction of chimeras, with phenotypes not readily transmissible to progenies.

The possibility to use genetic transformation to transfer genes, not only within and between plant species, but also from other kingdoms, has enhanced the tools usable by plant breeders, saving considerable time in the breeding process. In addition, endogenous genes can be overexpressed or silenced. New sets of genes affecting flowering, flower architecture, colour, scent and shelf-life are now available, but it remains a challenge to identify gene networks of interest. While in some countries (e.g. Canada, USA and Argentina), a product-based regulation on transgenic plants is enforced, allowing a case by case evaluation of new products, in EU and other countries a largely process-based regulation limits their commercial use. Thus, relevant procedures require an extensive risk assessment about potential effects to human health and the environment, with enormous costs often not affordable by breeders. Indeed, the only transgenic ornamental products which have so far been released to the market are flower colour-modified varieties: transgenic blue-hued carnations (Moonseries by Florigene) commercialized in Australia, Canada, the EU, Japan, Russia, United Arab Emirates and the US, and the blue-hued rose (Applause by Suntory Flowers) sold in Japan and the US (Kishi-Kaboshi et al. 2018). Recent results of high-throughput sequencing projects in ornamentals represent a concrete resource and a strong input for future breeding.

Genome editing approaches, particularly those based on CRISPR-derived technologies, allow the development of more precise and efficient tools to induce mutations in plant genes, modifying their expression or silencing them (Hahne et al. 2019). The possibility to implement such approaches in breeding of ornamental species, however, relies on information about structure and function of plant genomes and genes, and availability of efficient transformation and regeneration protocols. In this review, we update the genome editing applications in ornamental plants and critically discuss the status of enabling technologies and information on genes underlying traits of interest, focusing on the world's best-selling cut flowers, namely rose, lily, chrysanthemum, lisianthus, tulip, gerbera, freesia, alstroemeria, carnation and hydrangea.

\section{Flowering induction}

The ability to control flowering time is a crucial aspect in flower crops. Flowers could be produced and sold in less time and on special days, or when the market demand is 
higher. A central role in flowering induction pathway is occupied by the regulatory gene FLOWERING LOCUS T $(F T)$, which was first studied in the long-day thale cress (Turck et al. 2008) and in the short-day rice (Komiya et al. 2008). It belongs to the phosphatidylethanolamine-binding proteins (PEBPs) gene family. Environmental and developmental cues and their interplay with few floral pathway integrator genes modulate the transition of a meristem from vegetative to reproductive, causing the direct activation of the genes responsible of the floral meristem making (van Dijk and Molenaar 2017; Dennis and Peacock 2019). The circadian mRNA stabilization of the zinc-finger transcriptional regulator CONSTANS $(C O)$ links the fluctuations in the duration of the day and night to the floral integrator FT (Andrés and Coupland 2012). When the FT protein, translated in the leaf phloem during long days, reaches primary meristems, it positively activates SUPPRESSOR OF OVEREXPRESSION OF CONSTANCE 1 (SOC1) and APETALA 1 (APl) gene expression. The transcription of $F T$ and $S O C 1$ is in turn blocked by two flowering repressor genes FLOWERING LOCUS C (FLC) and SHORT VEGETATIVE PHASE (SVP). Low temperatures (vernalization) stop $F L C$ synthesis.

Few flowering induction genes have been sequenced and used to manipulate flowering in the ornamental species so far. In the commercial cultivars Lilium longiflorum 'White Heaven' and Tulipa gesneriana 'Dynasty' one and three $F T$ orthologue genes were isolated, respectively (LlFT and $T g F T 1, T g F T 2, T g F T 3$ ). The over-expression of LlFT and TgFT2 in Arabidopsis thaliana led to early flowering, while over-expression of $T g F T 1$ and $T g F T 3$ delayed flowering. Consistently with previous results, LlFT overexpression in L. longiflorum produced a precocious flowering too (Leeggangers et al. 2018).
$F T$ and $F T$-like genes have been isolated in the summer flowering cultivars 'Jinba' and 'Yuuka' of cut Chrysanthemum morifolium ( $C m F T$ and $C m F T L$ ). The over-expression in 'Yuuka' of the gene $C m B B X 8$ ( $C m F T L$ activator) induced the plants to flower 20 days earlier than the wild type; on the contrary, $C m B B X 8$ silencing delayed flowering of 15 days (Wang et al. 2020).

The approximate number of available gene sequences in cut flower species related to flower induction and other traits elaborated in this review are reported in Table 1, while some specific examples are included in Online Resources (ESM_1-ESM_6).

\section{Floral meristem initiation and organ development}

At flowering, the shoot meristem of flowering plants can undergo a programmed series of changes leading to a floral meristem. Mutant plants with abnormal flowers were used to identify the first genes involved in the floral meristem initiation. The transcription factors FLORICAULA from Anthirrhinum (Coen et al. 1990) and $L E A F Y$ ( $L F Y$ ) from Arabidopsis (Weigel et al. 1992) are responsible of the floral identity determination of the meristem, after floral induction. Early in the floral meristem development, both $L F Y$ and the MADS-box gene APl are highly expressed (GustafsonBrown et al. 1994). Several floral meristem identity genes have been isolated in many species and their exact role is still being studied (Chang et al. 2020).

A significant delay of the onset of flowering was observed in thale cress transgenic plants expressing the MADS-box gene SHORT VEGETATIVE PHASE (LOSVP) from oriental lily (Tang et al. 2020), lavander (Wells et al.

Table 1 Gene sequences available in GenBank (https://www.ncbi.nlm.nih.gov/) for the main commercial traits in the ten world's best-selling cut flower species ${ }^{\mathrm{a}}$

\begin{tabular}{|c|c|c|c|c|c|}
\hline Crop & $\begin{array}{l}\text { Flowering induc- } \\
\text { tion }\end{array}$ & $\begin{array}{l}\text { Floral meristem initiation and } \\
\text { organ development }\end{array}$ & Flower colour & Flower scent & $\begin{array}{l}\text { Flower } \\
\text { shelf } \\
\text { life }\end{array}$ \\
\hline Alstroemeria spp. & $-{ }^{b}$ & + & - & + & - \\
\hline Chrysanthemum x morifolium & + & ++ & +++ & + & + \\
\hline Dianthus spp. & - & + & +++ & - & + \\
\hline Eustoma exaltatum & + & - & ++++ & - & - \\
\hline Freesia $\mathrm{x}$ hybrida & + & + & ++ & + & + \\
\hline Gerbera $\mathrm{x}$ hybrida & + & + & ++ & - & + \\
\hline Hydrangea macrophylla & + & + & + & - & - \\
\hline Lilium spp. & + & + & ++++ & + & + \\
\hline Rosa x hybrida & + & + & ++ & ++ & + \\
\hline Tulipa spp. & + & - & ++ & - & - \\
\hline
\end{tabular}

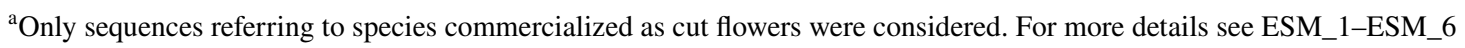

$\mathrm{b}_{-}=0 ;+=1-10 ;++=11-30 ;+++=31-50 ;++++>50$ sequences 
2020) and chrysanthemum (CmSVP) (Gao et al. 2017). The differentiating cells of the floral meristem build the architectural beauty of flowers in concentric whorls, consisting of a genetically determined sequence of four simple organs: from outside to inside, the sepals, the petals, the stamens and the carpels. The organogenetic process was clarified by studying homeotic mutants, in which the normal spatial organization was altered and one organ was replaced by another (Meyerowitz 1989). The expression of the first homeotic genes DEFICIENS from Anthirrinum (Sommer et al. 1990) and AGAMOUS (AG) from Arabidopsis (Yanofsky et al. 1990) specified the identity of the organ in a whorl. They encode transcription factors of the MADS-box family. The function of the organ identity genes was initially schematized according to "the ABC model of floral organ identity" (Coen and Meyerowitz 1991), soon relocated in the "ABCDE model" (Theißen and Saedler 2001) or in the "ABCE model" (Krizek and Fletcher 2005; Soltis et al. 2007). The similarity across many other plant species of floral organ position and similar homeotic mutants suggest that the model operates widely in angiosperms (Jack 2004; Sablowski 2010; Theißen et al. 2016; Liu et al. 2018).

Genes encoding transcription factors have been manipulated to improve flower traits and petal number in cyclamen. The concurrent shutdown of two AGAMOUS orthologues (CpAG1 and $C p A G 2$ ) induced a flower architecture with petal organs (up to 40) instead of stames and carpels, resembling the shape of hybrid tea rose flower (Tanaka et al. 2013). More than 1800 differentially expressed genes including regulatory genes for floral meristem and organ development were identified in ray florets and disc florets of chrysanthemum, following the comparative analysis of $C$. morifolium transcriptome (Liu et al. 2016). The careful study of a petal defect in a bud sport of C. morifolium 'Anastasia Dark Green' shed light on the many genes (auxin pathway, organ boundary, adaxial-abaxial polarity) that together regulate the hooked petal morphology. Transgenic plants with a constitutive expression of the chrysanthemum polarity gene homolog $(C m Y A B 1)$ showed flat petals with a reduced degree of bending. As a result, the inflorescence morphology was round and similar to a pompon (Ding et al. 2019). This study represented a reference point for other Asteraceae and has been recently updated (Ding et al. 2020). Lately, 30 candidate genes responsible for the marginal/ventral development of elaborate petals and the initiation of several specialized morphological characters have been identified in the model species Nigella damascena (Ranuncolaceae). In particular, LATE MERISTEM IDENTITY1 (NidaLMI1), encoding a class I homeodomain-leucine zipper family transcription factor, has been shown to play an important role in the development of trichomes and bifurcation of the lower lip (Zhang et al. 2020).
Non-coding RNA molecules (miRNAs) are involved in post-transcriptional regulation of target gene expression and have notable biological functions in plant development (Rubio-Somoza and Weigel 2011). They have a role in power on/power off of the cascade of transcription factors that induce flowering and actuate flower development, providing great potential in ornamental biotechnologies (Hong and Jackson 2015). Flowering was prevented in ornamental gloxinia (Sinningia speciosa) by raising miR159 levels, which in turn reduced the amounts of the gloxinia homologues of $L F Y$, three MADS-box genes and SsGAMYB, a component of gibberellin signaling. On the other hand, flowering occurred before and petals were converted into sepals when miR159 levels were reduced (Li et al. 2013). The opposite effects on flowering time was observed when miR172 was manipulated in gloxinia. The overexpression of miR 172 promoted flowering 50 days earlier than in wildtype plants and its suppression, using the mimicry target approach, caused a delay of 6 days (Li et al. 2019a, b). The target of the microRNA is the gloxinia APETALA2-like gene (SsAP2-like). Natural mutations affecting microRNA recognition sites displayed plants with double flowers in Dianthus caryophyllus, Petunia hybrida and Rosa rugosa commercial varieties. The disruption of the miR172 target sequence in the TOE-type genes called PETALOSA (PET) caused the development of a higher number of petaloid stamens in the clustered regularly interspaced short palindromic repeats/ CRISPR-associated 9 endonuclease (CRISPR/Cas9) edited Nicotiana tabacum plants, similarly to natural mutations occurring in double flower commercial varieties of carnation, petunia and $R$. rugosa (Gattolin et al. 2020).

A list of phenotypes and gene constructs introduced in carnation, chrysanthemum, eustoma, gentiana, pharbitis, rosa, and torenia is accessible in the Database for Flower Bio-engineering by CRES-T (https://www.cres-t.org/fiore/ public_db/index.shtml; Mitsuda et al. 2011). Some examples of organ and meristem identity genes and their orthologues in ornamental cut flowers are reported in ESM_2.

\section{Flower colour}

The two most representative pigments responsible for flowers' colours are flavonoids (in particular anthocyanins, anthocyanidins, flavonols and flavones) and carotenoids (carotenes and xanthophylls). Other compounds involved in pigmentation are betalains (betacyanins and betaxanthins), that are specific and present in some Caryophyllales instead of anthocyanins, and chlorophylls ( $\alpha$ and $\beta$ ), that are responsible for few and rare cases of green flowers. Histological observations revealed that pigments have proper subcellular location and they are mainly located in the upper epidermal cells of petals. Flavonoids are accumulated into vacuoles, 
whereas carotenoids are deposited in plastids ( $\mathrm{Ng}$ and Smith 2016). The morphology of petal epidermal cells contributes to flower colour: when the light can penetrate and be adsorbed into conical cells flowers will show dark colour, whereas flat cells reflect light wavelength promoting pale flowers (Grotewold 2006). The presence of empty spaces between the cells of the epidermal layers, the characteristic structure of the cell wall combined with the effect of incident light are responsible for the colour of the petals of different species belonging to Papaveraceae family (van der Kooi and Stavenga 2019).

Flavonoids have been extensively studied in ornamental species, some of them being considered model plants. Plenty of information is now available in petunia (Tornielli et al. 2009), herbaceous peony (Zhao et al. 2012), Torenia fournieri (Nishiara et al. 2018), Ipomoea nil (Watanabe et al. 2017), I. purpurea (Durbin et al. 2003), C. morifolium (Ohmiya 2018) and rose (Wan et al. 2019).

Flavonoids containing anthocyanidyns provide colours as orange red (pelargonidin), purplish red (cyanidin), blue (delphinidin), purple violet (malvidin), rose (peonidin), and purple violet (petunidin), while those containing anthoxanthins give rise to white, light and dark yellow. The anthocyanin biosynthetic cascade is well known and three steps are characterized by specific genes: 1) phenylalanine ammonia lyase (PAL), cinnamate-4-hydroxylase $(C 4 H)$, and 4-coumarate: CoA ligase $(4 C L) ; 2)$ chalcone synthase (CHS), chalcone isomerase (CHI), flavanone-3-hydroxylase $(F 3 H)$, flavonoid 3'-hydroxylase $\left(F 3^{\prime} H\right)$, and flavonoid 3',5'-hydroxylase $\left.\left(F 3^{\prime} 5^{\prime} H\right) ; 3\right)$ dihydroflavonol 4-reductase $(D F R)$, anthocyanidin synthase (ANS), flavonoid glucosyltransferase (UFGT), and methyl transferase (MT).

CHS is the first enzyme in the flavonoids metabolic flow and it is ubiquitous in ornamental plants. As reported by Rosati and Simoneau (2006), down-regulation with antisense $C H S$ construct caused the complete loss of pigmentation resulting in white flowers in petunia and chrysanthemum. Sun et al. (2015) transformed petunia with CHSI of Freesia obtaining new plants with pink flowers. Again, in petunia, a family of $C H S$ genes was identified and posttranscriptional regulation led to different pigmentation of the corolla (Koseki et al. 2005). In D. caryophyllus and in cyclamen mutants, a low $\mathrm{CHI}$ expression induced the formation of yellow flowers (Nishihara et al. 2005), while purple minicyclamen turned into red/pink petals when $F 3^{\prime} 5^{\prime} H$ gene was switched off (Boase et al. 2010). In Osteospermum, a co-suppression of $F 3^{\prime} 5^{\prime} H$ and $F 3^{\prime} H$ genes altered the anthocyanin biosynthesis (Seitz et al. 2007). In rose and carnation, $F^{\prime} 5^{\prime} \mathrm{H}$ gene is not present, hence they do not have bluish petals (Noda 2018). With the aim to obtain the missing colour in rose, Katsumoto et al. (2007) successfully observed a new blue phenotype in transformed plants with $F 3^{\prime} 5^{\prime} H$ from Viola together with DFR from Iris x hollandica. DFR was sequenced in gentian (Nakatsuka et al. 2008), while a gene family, made by three $D F R$ genes, has been isolated in petunia (Tornielli et al. 2009). Wellmann et al. (2006) described the role of ANS in gerbera, showing the direct involvement of this gene in plant colour pattern.

$R 2 R 3-M Y B$ and $b H L H$ (basic helix-loop-helix) transcription factors, combined with WD40 proteins, are involved in the anthocyanin pathway, acting as regulatory elements (Naing and Kim 2018). The synergistic interaction with structural genes was described in Phalaenopsis (Hsu and Chen 2017) and Lilium regale (Yamagishi 2016).

Even if flavonols are noncolored flavonoids, their involvement on flowers colour process can be observed only in combination with anthocyanins. The intermolecular copigmentation is responsible for increased petal pigmentation. Flavonol synthase (FLS) is involved in the synthesis of flavonols and the competition with $D F R$ for the common substrate was described in petunia (Tornielli et al. 2009).

A specific pigmentation depends on the presence of carotenoids: red-orange is typical of carotenes ( $\alpha$-carotene and $\beta$-carotene), while orange-yellow is due to the presence of xanthophyllys (Nisar et al. 2015). Brilliant colours of some important ornamentals are mostly due to the presence of these pigments. Only when carotenoids are co-expressed with dark red or purple anthocyanins, it is possible to appreciate flowers with unique and attractive copper brown colour (Grotewold 2006). Since carotenoids are involved in many other important aspects of the plant (they are involved in photoprotection, nutraceutical value, and are precursors of vitamin A and of abscisic acid), the key genes have been identified and characterized: phytoene synthase (PSY), phytoene desaturase (PDS), zeta-carotene desaturase (ZDS), carotenoid isomerase (CRTISO), lycopene epsilon-cyclase (LCYE) and lycopene beta-cyclase (LCYB). In Mimulus lew$i s i i$, a R2R3-MYB transcription factor plays a crucial role on carotenoid metabolism (Sagawa et al. 2016).

Genes determining the colour in some cut flowers, through the flavonoid and carotenoid biosynthetic pathways, are reported in Online Resource 3 (ESM_3) and 4 (ESM_4), respectively. Many gene sequences are available in GenBank (Table 1).

\section{Flower scent}

The fragrance of flowers is specific to each plant and is made up of a mixture of small (100-250 Da) volatile molecules that mostly belong to three groups of compounds: terpenoids, phenylpropanoids / benzenoids, and fatty acid derivatives (Vainstein et al. 2001; Guterman et al. 2002; Kumari et al. 2017). The VOCs (volatile organic compounds) are synthetized mainly in flowers (largely in the petals), although they are found also in roots, stems, leaves, 
seeds and fruits (Muhlemann et al. 2014; Abbas et al. 2019; Ramya et al. 2020).

Terpenoids, divided into monoterpenoids and sesquiterpenoids, are the largest class of floral volatiles. They derive from the MVA (mevalonic acid) and MEP (methylerythritol phosphate) pathways in the cytosol and plastids, respectively (Xiang et al. 2007; Abbas et al. 2017). Terpene synthases (TPSs) are the key enzymes in the biosynthetic pathways of terpenoids (Tholl 2006, 2015). Monoterpenes, which include limonene, (E)-b-ocimene, myrcene, linalool, and alpha- and beta-pinene, are commonly found in floral volatiles of lilium, rose, orchid, snapdragon, petunia, Freesia, Alstroemeria, Clarkia, Iris (Du et al. 2019). The second major class of plant VOCs are represented by phenylpropanoids and benzenoids and derive from shikimic acid via phenylanaline, cinnamic acid and further decarboxylation and ring oxidation (Dunkel et al. 2009; Duradeva 2002; Knudsen et al. 2006). They characterize the floral scent of different species: Silene, Clarkia, snapdragon, petunia and rose (Muhlemann et al. 2014). The third class of flower VOCs are the fatty acid derivatives, which are synthesized via the lipoxygenase pathway from the unsaturated $\mathrm{C} 18$ linoleic and linolenic fatty acids. The products, short chain alcohols and aldehydes, are important constituents in the floral volatile perfume of several plant species such as carnation, wild snapdragon and orchids of genus Ophrys (Muhlemann et al. 2014). 'SCENTbase' and 'SuperScent' are two databases in which plant volatile chemicals are collected (Knudsen et al. 2006; Dunkel et al. 2009; Fan et al. 2019).

Prior to the development of high-throughput technologies, only classic biochemical approaches could be applied to isolate floral scent genes. In the last few years, NGS technologies through transcriptome and genome analysis of large numbers of active genes combined with complex metabolite networks and advances in gas chromatography-mass spectrometry (GC-MS) analysis allowed the identification of novel scent genes in several ornamental species (ESM_5).

Garden roses are selected primarily for fragrance, whereas marketed roses bred for cut flower production often lack perfume, notwithstanding the efforts of breeders (Smulders et al. 2019). In reality, even fragrance-free roses emit small quantities of fragrant molecules, as it would seem that they have not completely lost their ability to produce them, but according to a recent hypothesis, it would be a malfunction of the biosynthetic pathway of VOCs (Baudino et al. 2019). Unfortunately, the biosynthetic pathways of many rose scent compounds are not completely known. To identify genes involved in rose scent, high-throughput transcriptomic approaches were applied to petal tissues (ESM_5). The phenolic methyl ethers were first investigated as responsible for the characteristic sweet "tea scent" smell of some chinese roses. This unique scent is rich in 3,5-dimethoxytoluene (DMT), that is synthesized by two specific enzymes, orcinol-Omethyl transferases 1 and 2 (OOMT1 and OOMT2) (Baudino et al. 2019). The key enzymes phenylacetaldehyde synthase and phenylacetaldehyde reductase were identified based on a detailed study of the main 2-phenylethanol (2PE) pathway (Smulders et al. 2019). Yan et al. (2018) suggested that a eugenol synthase (RcEGSI) cloned from the petals of $R$. chinensis 'Old Blush' (Wang et al. 2012) is involved in the biosynthesis of eugenol in rose, studying its over expression and down regulation by gene silencing. Terpenoids, especially monoterpene alcohols such as geraniol, are central molecules for the 'typical rose scent'. Nevertheless, only few genes of the terpenoid pathway have been characterized: a sesquiterpene synthase, for the biosynthesis of germacrene $\mathrm{D}$, and two monoterpene synthases for linalool and nerolidol, although these are not the main terpenoids in rose (Magnard et al. 2018). It has been recently discovered that rose uses a terpene synthase independent pathway to produce geraniol. The expression of RhNUDX1, a diphosphohydrolase enzyme of the Nudix family, is strongly correlated with the presence of terpenoids in different rose cultivars (Magnard et al. 2015).

In lilium "Siberia", a commercially important cv appreciated by the consumer for its fragrance and large and snowy white flowers (Hu et al. 2013, 2017), two monoterpene synthase genes (LoTPS1 and LoTPS3), responsible for biosynthesis of $\beta$-ocimene and linalool, were isolated and functionally characterized. These monoterpenes compounds were released following a diurnal circadian rhythm. The expression of both genes occurs in sepals and petals in response to mechanical injury (Abbas et al. 2019). Through the analysis of the volatile emissions from 41 Lilium cvs, Du et al. (2019) classified various flower aroma types and identified monoTPS polymorphisms and alternative splicing products.

In orchids, Hsiao et al. (2006, 2008) have reported the monoterpenoid biosynthesis pathway and responsible genes in Phalaenopsis bellina and P. equestris; in particular, the tissue and temporal expression of glyceraldehyde-3-phosphate (GDPS), precursor of geraniol and linalool has been elucidated. Chuang et al. (2017) studied the expression of $P b G D P S$ and the regulation by several transcription factors of putative monoterpene synthases, terpene synthase 5 (PbTPS5) and PbTPS10, during flower development. In the Vanda orchid, a new 1-deoxy-D-xylulose 5-phosphate reductoisomerase $(D X R)$ transcript was reported (Chan et al. 2009) and two fragrance-related transcripts, VMPAAT encoding a putative alcohol acyltransferase and VMPSTS encoding a sesquiterpene synthase, were cloned and characterized (Chan et al. 2011). In Gymnadenia spp., GoEGSI, GoEGS2, GcEGS1, and GcEGS2 are involved in the phenylpropanoid formation of eugenol and the relevant pathway has been described (Gupta et al. 2014). Xu and colleagues (2019) have analyzed the biosynthetic flower scent pathways 
in Cymbidium faberi and characterized the function of its jasmonic acid carboxyl methyltransferase (CfJMT).

RNASeq in lavender (Lavandula) allowed the discovery of S-linalool synthase (LiS-LINS), that is important as it imparts a sweet scent to the lavender oils to enhance the market value (Adal et al. 2019).

Finally, in a recent article, Fan et al. (2019) investigated the floral scent compositions within the genus Camellia, uncovering remarkable interspecific variation in composition and quantity.

\section{Flower shelf life}

Increasing vase life is a key factor to convince consumers to re-purchase cut flowers. To extend the life of the flower after harvesting, it is necessary to act on several factors before harvesting, including genotype choice. In many flowers, post-harvest life depends on the appearance of the first symptoms of petal senescence which show the characteristic "in-rolling" behavior, but also other symptoms may also appear such as wilting, colour change, petal and bud abscission (Olsen et al. 2015). These symptoms can be delayed by treatments that block the biosynthesis or action of ethylene (Shibuya et al. 2004).

Quite often, the quality and vase life of flowers is related to the amount of exogenous and endogenous ethylene, a phytohormone that plays a central role in various metabolic plant processes, such as seed germination, but also flower and leaf senescence. The most important cut flower species, as rose, lilium, lisianthus, chrysanthemum or carnation show different levels of sensitivity to ethylene and even different flower longevity. In many of these species, breeding approaches, based on cross-pollination coupled with ethylene screening, have been applied with little success. An alternative solution to improve ornamental's vase life can be the exploitation of molecular approaches (Netam 2018).

In carnation, transcripts for the various steps of the ethylene biosynthetic pathway have been identified by transcriptomic analysis (Tanase et al. 2012). In Rosa hybrida, ethylene-responsive transcript, potential key regulators of ethylene-influenced cell expansion, were also identified using a floral transcriptome (Pei et al. 2013). In the last years, however, many studies focused on the knowledge of ethylene biosynthesis. Onozaki et al. (2011), by repeated selection for longer vase life, produced two carnation cultivars improved for that trait. Their flowers showed a reduced expression of the three ethylene biosynthesis genes: 1-aminocyclopropane-1-carboxylate synthase (DcACS1 and DcACS2) and 1-aminocyclopropane-1-carboxylate oxidase (DcACO1). Further, transgenic plants with longer vase life were obtained by introducing genes encoding 1-aminocyclopropane-1-carboxylate (ACC) degrading enzymes. In $D$. caryophyllus, Torenia, Petunia, and Begonia, the antisense technology has been successfully attempted for ACS (ACC synthase) and $A C O$ (ACC oxidase), key enzymes of ethylene biosynthesis. In carnation, by silencing $A C O$, vase life was almost doubled compared to the original variety, increasing from 5 to 9 days (Chandler 2007; Savin et al. 2019).

The ethylene receptor 1 (etrl-1) appeared to be a key gene for further manipulation. In comparison with nontransformed plants, petunias expressing constitutively a mutated etrl-1 transgene from Arabidopsis were insensitive to ethylene and showed larger flowers with a longer vase life (Clevenger et al. 2004). They, however, showed a negative effect in several morpho-physiological traits. Normal plants with flowers showing higher longevity could be obtained in kalanchoë, Campanula, and D. caryophyllus using a flowerspecific fructose-bisphosphatase 1 ( FBP l) promoter driving the expression of the same transgene (Olsen et al. 2015). Other genes, tested in Nemesia strumosa and T. fournieri, were less successful than etrl-1 of Arabidopsis.

In Japanese morning glory (I. nil), functional studies highlighted the role of a NAC (NAM/ATAF1,2/CUC2) type transcription factor, EPHEMERAL 1 (EPH1), in the control of ethylene-independent flower senescence (Shibuya et al. 2014).

\section{Genomic resources}

Structural and functional information about gene networks and genomes is of paramount importance to develop breeding approaches based on genome editing. However, complexity and size of ornamental plant genomes, as well as their heterozygosity and/or polyploidy have slowed the development of genomic resources in such species. Only recently, new technological tools for sequencing and analyzing large data sets could be applied to a number of ornamentals (Yagi 2018).

The whole genome sequence has been been reported in carnation (Yagi et al. 2014), Dendrobium officinale (Yan et al. 2015), D. catenatum (Zhang et al. 2016b), Primula veris (Nowak et al. 2015), Phalaenopsis (Cai et al. 2015; Chao et al. 2018), Petunia (Bombarely et al. 2016), I. nil (Hoshino et al. 2016), Hibiscus syriacus (Kim et al. 2017), Helianthus annuus (Badouin et al. 2017), Rosa chinensis (Saint-Oyant et al. 2018), Antirrhinum majus (Li et al. 2019a) and Chrysanthemum seticuspe (Hirakawa et al. 2019). The latter is a diploid wild relative of cultivated chrysanthemum and was used to resolve the genetic complexity of hexaploid varieties (Table 2). In addition, a whole genome shotgun sequencing strategy, leading to partial genome sequences, was used for Aquilegia coerulea (Filiault et al. 2018), Catharanthus roseus (L.) G. Don (Kellner et al. 
Table 2 Whole genome sequences of some cut flowers and other ornamental species (Yagi 2018; modified)

\begin{tabular}{|c|c|c|c|c|}
\hline Species & Sequencing technology & $\begin{array}{l}\text { Estimated } \\
\text { genome } \\
\text { size }\end{array}$ & Chromosome number & References \\
\hline Antirrhinum majus & HiSeq2000, PacBio & $520 \mathrm{Mb}$ & $2 n=2 x=16$ & Li et al. 2019a, b \\
\hline Chrysanthemum seticuspe & Illumina HiSeq 2000 and MiSeq & $3.0 \mathrm{~Gb}$ & $2 n=2 x=18$ & Hirakawa et al. 2019 \\
\hline C. nankingense & Oxford Nanopore & $3.0 \mathrm{~Gb}$ & $2 n=2 x=18$ & Song et al. 2018 \\
\hline Dendrobium catenatum & HiSeq2000 & $1.1 \mathrm{~Gb}$ & $2 n=2 x=38$ & Zhang et al. 2016a, b, c \\
\hline D. officinale & HiSeq2000, PacBio & $1.3 \mathrm{~Gb}$ & $2 n=2 x=38$ & Yan et al. 2015 \\
\hline Dianthus caryophyllus & $\begin{array}{l}\text { HiSeq1000, GS } \\
\text { FLX }+\end{array}$ & $622 \mathrm{Mb}$ & $2 n=2 x=30$ & Yagi et al. 2014 \\
\hline Helianthus annuиs & PacBio RS II & $3.6 \mathrm{~Gb}$ & $2 n=2 x=34$ & Badouin et al. 2017 \\
\hline Hibiscus syriacus & HiSeq2000 & $1.9 \mathrm{~Gb}$ & $2 n=4 x=80$ & Kim et al. 2017 \\
\hline Ipomoea nil & PacBio, HiSeq2500 & $750 \mathrm{Mb}$ & $2 n=2 x=30$ & Hoshino et al. 2016 \\
\hline Petunia axillaris & HiSeq2500, PacBio & $1.4 \mathrm{~Gb}$ & $2 n=2 x=14$ & Bombarely et al. 2016 \\
\hline P. inflata & HiSeq2500, PacBio & $1.4 \mathrm{~Gb}$ & $2 n=2 x=14$ & Bombarely et al. 2016 \\
\hline Phalaenopsis equestris & HiSeq 2000 & $1.2 \mathrm{~Gb}$ & $2 n=2 x=38$ & Cai et al. 2015 \\
\hline P. aphrodite & GAIIX, HiSeq & $1.20 \mathrm{~Gb}$ & $2 n=2 x=38$ & Chao et al. 2018 \\
\hline Primula veris & $\begin{array}{l}\text { Hiseq2000, Miseq, } \\
\text { Ion Proton, PacBio }\end{array}$ & $479 \mathrm{Mb}$ & $2 n=2 x=22$ & Nowak et al. 2015 \\
\hline Rosa chinensis & HiSeq2500, PacBio & $512 \mathrm{Mb}$ & $2 \mathrm{n}=2 x=14$ (double haploid line) & Saint-Oyant et al. 2018 \\
\hline R. multiflora & Illumina MiSeq and HiSeq 2000 platforms & $711 \mathrm{Mb}$ & $2 \mathrm{n}=2 \mathrm{x}=14$ & Nakamura et al. 2018 \\
\hline Salvia splendens & PacBio RS II; Illumina HiSeq X Ten & $711 \mathrm{Mb}$ & $2 n=2 x=44$ & Dong et al. 2018 \\
\hline
\end{tabular}

2015), Phalaenopsis aphrodite (Chao et al. 2018) and Rosa roxburghii Tratt (Lu et al. 2016).

Furthermore, comprehensive transcriptome sequencing from various tissues has been carried out. Recently, Wei et al. (2020) identified key carotenoid genes and studied their expression levels in Ornithogalum dubium with the aim to modulate flower colour via genome editing. Examples of transcriptome datasets for main ornamental plant species and commercial traits, obtained using NGS technology, are reported in Table 3 and Online Resource 7 (ESM_7). For some ornamental plant families, transcriptome assembly databases have been recently developed: Genome Database for Rosaceae (GDR) (https://www.rosaceae.org/); Carnation DB (https://carnation.kazusa.or.jp//; Sol Genomics Network (https://solgenomics.net/) for Solanaceae; Orchidstra 2.0 (https://orchidstra2.abrc.sinica.edu.tw/orchidstra2/) for the orchid family (Chao et al. 2017); Plant Genome DataBase Japan (https://pgdbj.jp/index.html?ln=en) for chrysanthemum, carnation and Ipomea nil.

\section{Plant regeneration and genetic transformation}

Despite protoplast- and biolistics-based methods have been used in some cases, direct shoot regeneration from different plant tissues (cotyledon, leaf, petiole, stem, petal, root, protocorm, etc.), previously co-cultivated with engineered
Agrobacterium strains, is the most widespread way to obtain transgenic ornamental plants (Chandler and Brugliera 2011; Kishi-Kaboshi et al. 2018; Boutigny et al. 2020). Plant regeneration and transformation efficiency are often cultivardependent and attempts to find efficient protocols are expensive and time consuming (Aragão and Cid 2006; Chandler and Sanchez 2012). Examples of transformation technology, explant types and transgene traits in some of the world's best-selling cut flowers are reported online (ESM_8). Amenability of cut flowers species to in vitro methods for transformation and regeneration is synthesized in Fig. 1.

\section{Genome editing}

Current genome editing approaches rely on the induction of specific cuts in double-strand DNA (DSB, double-strand breaks) at a target site. In absence of any template, such cuts are "repaired" through non-homologous end joining (NHEJ), generally leading to small insertions or deletions. By contrast, in the presence of a template, either desired point mutations or gene insertions/replacements can be induced at a pre-selected site by homology directed repair (HDR). The most recent, versatile and efficient system is based on the CRISPR/Cas9 molecules (Hilscher et al. 2017; Ahn et al. 2020).

In proof of concept studies, NHEJ-based genome editing was successfully applied in petunia ( $P$. hybrida). DNA 
Table 3 Transcriptome datasets obtained using NGS in top ten cut flowers (Yagi 2015; modified)

\begin{tabular}{|c|c|c|c|}
\hline Species & Tissue & Aims & Reference \\
\hline Chrysanthemum morifolium & Ray florets, disc florets and leaves & $\begin{array}{l}\text { Flower development, flower organ determi- } \\
\text { nation, anthocyanin biosynthetic genes }\end{array}$ & Liu et al. 2016 \\
\hline Dianthus caryophyllus & $\begin{array}{l}\text { Flower buds, flower at different stage of bloom- } \\
\text { ing, leaves, stems } \\
\text { Stems at different flower development stage } \\
\text { before blooming }\end{array}$ & $\begin{array}{l}\text { Flower colour and vase life } \\
\text { Vase life }\end{array}$ & $\begin{array}{l}\text { Tanase et al. } 2012 \\
\text { Boxriker et al. } 2017\end{array}$ \\
\hline Freesia hybrida & $\begin{array}{l}\text { Buds at three different flowering stages } \\
\text { Petal tissues collected at four different develop- } \\
\text { ment stages }\end{array}$ & $\begin{array}{l}\text { Flower scent biosynthesis } \\
\text { Anthocyanin biosynthetic genes }\end{array}$ & $\begin{array}{l}\text { Huang et al. } 2018 \\
\text { Tang et al. } 2018\end{array}$ \\
\hline $\begin{array}{l}\text { Lilium } \\
\text { L.'Siberia' }\end{array}$ & $\begin{array}{l}\text { Bulb scales, axillary buds, stem, leaves and } \\
\text { floral bud; flowers during blooming and at } \\
\text { full anthesis of the flowers } \\
\text { Full bloomed flower }\end{array}$ & $\begin{array}{l}\text { Further genomics studies in bulbous plants } \\
\text { Flower scent biosynthesis }\end{array}$ & $\begin{array}{l}\text { Shahin et al. } 2012 \\
\text { Abbas et al. } 2019\end{array}$ \\
\hline Rosa chinensis & $\begin{array}{l}\text { Petals at different developmental stages, from } \\
\text { flower buds to senescent flower }\end{array}$ & Flower scent biosynthesis & Yan et al. 2014 \\
\hline R. odorata var. gigantea & $\begin{array}{l}\text { Vegetative meristem, pre-floral meristem, floral } \\
\text { meristem and secondary axillary buds }\end{array}$ & Floral transition & Guo et al. 2018 \\
\hline R. rugosa & $\begin{array}{l}\text { Petals of the three } R \text {. rugosa varieties at differ- } \\
\text { ent developmental stages }\end{array}$ & Flower colour variation & Sheng et al. 2018 \\
\hline R. species & Flowers at floral opening stage & Ethylene-regulated flower opening & Pei et al. 2013 \\
\hline R. species & Flowers at various developmental stages & Flower development & Kim et al. 2012 \\
\hline Tulipa & $\begin{array}{l}\text { Bulb-scales, axillary buds, stem, leaves and } \\
\text { floral bud; flowers during blooming and at } \\
\text { full anthesis of the flowers }\end{array}$ & Further genomics studies in bulbous plants & Shahin et al. 2012 \\
\hline
\end{tabular}

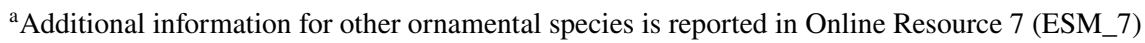

sequences encoding Cas9 and sgRNA were sequentially introduced in leaf discs by Agrobacterium-mediated transformation. When the phytoene desaturase (PDS), involved in the carotenoid biosynthesis, was used as target gene, $55.6 \%-87.5 \%$ of regenerated shoots showed an albino phenotype and insertions/deletions at the molecular level (Zhang et al. 2016a). In another study (Subburaj et al. 2016), the preassembled purified Cas9-sgRNA ribonucleoprotein (RNPs) was directly delivered into protoplasts to silence the nitrate reductase gene. Targeted deep DNA sequencing revealed average mutation rate (deletions and insertions) of $11.5 \%$. Albeit Lilium species generally show lower transformation efficiency than petunia, the Agrobacteriummediated transformation efficiency was improved using somatic embryogenesis and adventitious bud regeneration for L. pumilum and for L. longiflorum 'White Heaven'. Base insertions, deletions and substitutions in the phytoene desaturase $(L p P D S)$ were induced in such species, obtaining a range of completely albino, pale yellow and albino-green chimeric mutants (Yan et al. 2019). Finally, an artificial model based on transgenic GFP-expressing plants was used in the very large genome hexaploid species $C$. morifolium, which lacks detailed genomic information (Kishi-Kaboshi et al. 2017). CRISPR/Cas9 directed to the GFP transgene efficiently decreased its fluorescence in transgenic plants, with the Petroselinum crispum ubiquitin (PcUbi) promoter showing a better activity than the viral $35 \mathrm{~S}$ when used to drive Cas9 expression. Authors reasoned that the presence of multicopies of the transgene would mimic the hexaploidy of the target genome (Table 4).

With the advancement of new biotechnological tools and molecular information in ornamentals, genome editing proved to be functional also for targeted mutagenesis of genes controlling colour, form, and longevity of flowers. In $I$. nil, white flower could be obtained after targeting the dihydroflavonol-4-reductase-B (InDFR-B) (Watanabe et al. 2017). Regenerated plants with biallelic short indels mutations in the targeted gene resulted in the complete inactivation of the anthocyanin biosynthesis and in white flowers; on the other hand, monoallelic mutants showed violet flowers, as per no-edited plants. Periclinal chimaeras were also observed in some cases. $\mathrm{T}_{2}$ plants with the targeted mutation could be obtained from plants with (at the least) the $\mathrm{L}_{2}$ histogenic layer mutated. Among offsprings, some mutant plants without T-DNA insertions were obtained thanks to independent segregation. Interestingly, no off-target mutations were observed in the two paralogue genes InDFR-A and InDFR-C. The same authors also successfully induced the white petals of I. nil (mutant line AK77) to turn pale yellow increasing the amounts of carotenoids in petals by knocking-out the carotenoid cleavage dioxygenase (InCCD4) (Watanabe et al. 2018). As in the former case, CRISPR/ 
Fig. 1 Availability of in vitro transformation and regeneration protocols for the ten world's best-selling cut flowers: $0=$ not available protocols; $1=$ basic protocols; $2=$ routine protocols for model varieties; $3=$ efficient routine protocols for commercial varieties. Examples of transformation and regeneration protocols in some cut flowers are reported in Online Resource 8 (ESM_8)

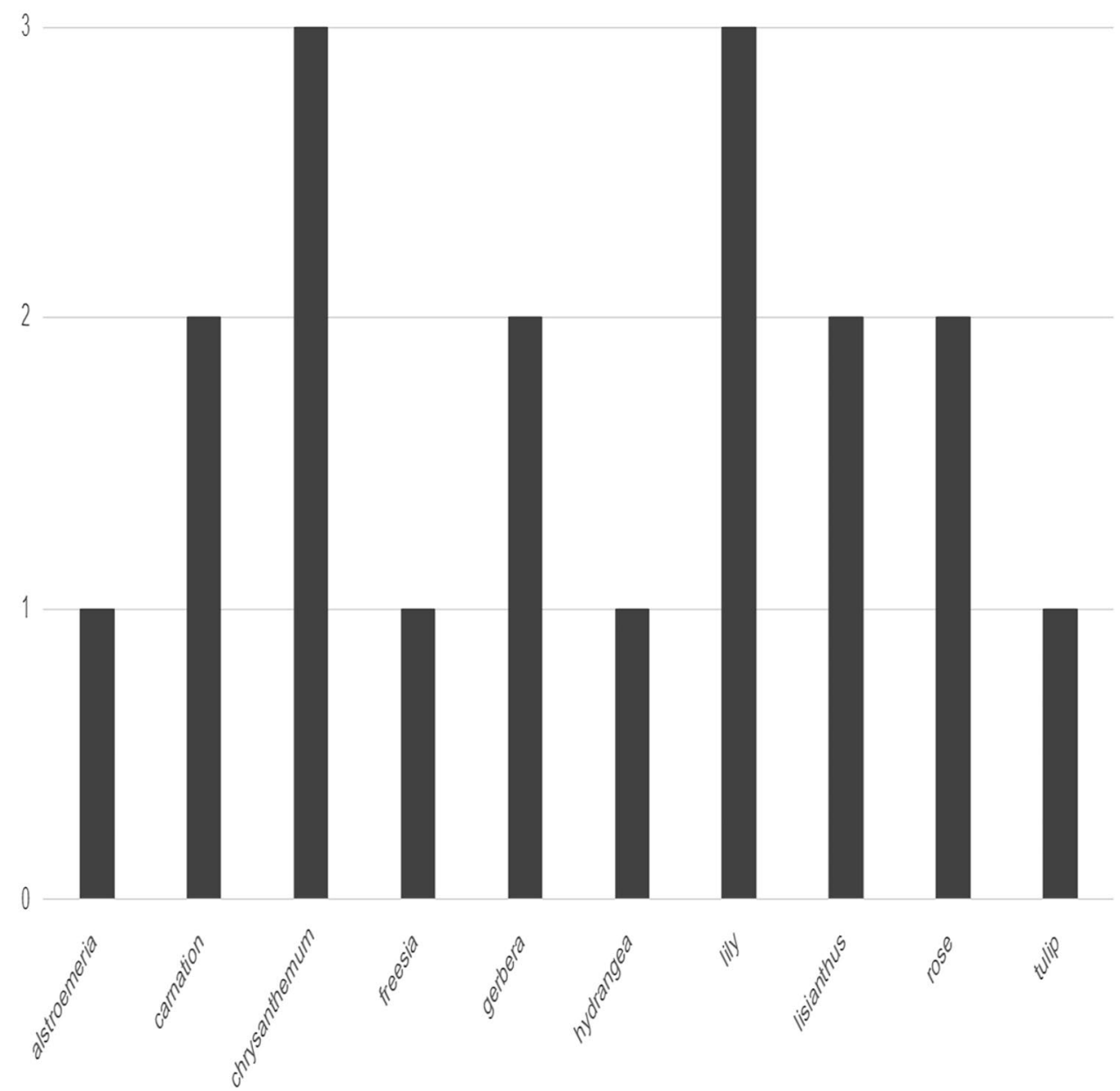

Cas9 constructs were inserted in plant cells by Agrobacterium-mediated transformation. Only biallelic mutants with a frame-shift mutation in both alleles showed pale yellow midribs; no changes in petal colour could be observed in monoallelic or chimaeric mutant plants. Since no change in expression of genes involved in carotenoid accumulation was observed, CCD4 loss-of-function was responsible of the increasing of carotenoids concentration (about 20-fold) in edited $c c d 4$ flowers. Flower colour mutants could be also obtained in T. fournieri by targeting the flavanone 3-hydroxylase $(F 3 H)$ gene, a key enzyme gene in the flavonoid biosynthetic pathway, using CRISPR/Cas9 and Agrobacteriummediated transformation (Nishihara et al. 2018). About $80 \%$ (20/24) of primary transformants displayed flower colour changes, the remaining being violet as wild-type plants. Among mutants, fifteen lines had faint blue (almost white) flowers and homozygous or heterozygous mutations in both $\mathrm{F} 3 \mathrm{H}$ alleles (biallelic mutations); pale violet lines were in most cases heterozygous for monoallelic mutations. However, by contrast with an available control white-flowered cultivar, low levels of anthocyanins could be detected in the $\mathrm{F} 3 \mathrm{H}$-edited plants. In the greenhouse, the faint blue flowers continued to bloom for more than 3 months and the flower colour was stable. Flowering time and plant height were similar to the wild type lines.

In T. fournieri, a species with zygomorphic flowers showing an asymmetric pigmentation pattern, targeted mutagenesis by CRISPR/Cas9-mediated genome editing was also used to study the role of a RADIALIS-like gene (TfRADI) in determination of petal shape, corolla symmetry and pigmentation pattern. TfRAD1-Cas9 with loss-of-function alleles had flowers with abnormal shape and pigmentation (Su et al. 2017). In a recent study, the number of petals was increased in T. fournieri MADS-box mutants. The single knockout of PLENA gene (TfPLE) caused morphological changes only in the carpels, the mutation of FALINELLI gene (TfFAR) resulted in no morphological changes, while the double biallelic plants showed the conversion of stamens and carpels into petal-like structures, suggesting that the two genes play a cooperative and synergistic role in reproductive organs development (Sasaki and Ohtsubo 2020). Three MADS genes, involved in flower initiation and development, were knocked-out in the orchid P. equestris using two multiplexing approaches (Tong et al. 2020). When the three sgRNAs were combined in a single vector, $60 \%$ of explants produced nonchimaeric triple $M A D S$-null mutants with homozygous 
Table 4 Genome editing approaches applied to ornamental crops

\begin{tabular}{|c|c|c|c|c|c|c|}
\hline Species & Target genes & Traits & $\begin{array}{l}\text { Genome editing } \\
\text { system }\end{array}$ & $\begin{array}{l}\text { Transformation } \\
\text { technology }\end{array}$ & Plant regeneration & References \\
\hline $\begin{array}{l}\text { Chrysanthemum } \\
\text { morifolium }\end{array}$ & CpYGFP & GFP fluorescence & CRISPR/Cas9 & $\begin{array}{l}\text { Agrobacterium } \\
\text { tumefaciens }\end{array}$ & Young leaf & $\begin{array}{l}\text { Kishi-Kaboshi et al. } \\
2017\end{array}$ \\
\hline $\begin{array}{l}\text { Dendrobium } \\
\text { officinale }\end{array}$ & $\begin{array}{l}C 3 H, C 4 H, 4 C L \\
\quad C C R, I R X\end{array}$ & $\begin{array}{l}\text { Reduced ligno cel- } \\
\text { lulose biosyn- } \\
\text { thesis }\end{array}$ & CRISPR/Cas9 & A. tumefaciens & Protocorms & Kui et al. 2017 \\
\hline Ipomoea nil & InDFR-B & $\begin{array}{l}\text { Flower colour } \\
\text { changes }\end{array}$ & CRISPR/Cas9 & A. tumefaciens & $\begin{array}{l}\text { Immature embryo- } \\
\text { derived second- } \\
\text { ary embryo }\end{array}$ & $\begin{array}{l}\text { Watanabe et al. } \\
2017\end{array}$ \\
\hline I. nil 'AK77' & InCCD4 & $\begin{array}{l}\text { Flower colour } \\
\text { changes }\end{array}$ & CRISPR/Cas9 & A. tumefaciens & $\begin{array}{l}\text { Immature embryo- } \\
\text { derived second- } \\
\text { ary embryo }\end{array}$ & $\begin{array}{l}\text { Watanabe et al. } \\
2018\end{array}$ \\
\hline I. nil 'AK77' & EPHI & Flower senescence & CRISPR/Cas9 & A. tumefaciens & $\begin{array}{l}\text { Immature embryo- } \\
\text { derived second- } \\
\text { ary embryo }\end{array}$ & Shibuya et al. 2018 \\
\hline $\begin{array}{l}\text { Lilium pumilum } \\
\text { DC. Fisch }\end{array}$ & $L p P D S$ & $\begin{array}{l}\text { Albino, pale yel- } \\
\text { low and albino- } \\
\text { green chimeric } \\
\text { mutants }\end{array}$ & CRISPR/Cas9 & A. tumefaciens & Embryogenic calli & Yan et al. 2019 \\
\hline $\begin{array}{l}\text { L. longiflorum } \\
\text { 'White Heaven' }\end{array}$ & $L I P D S$ & $\begin{array}{l}\text { Albino, pale yel- } \\
\text { low and albino- } \\
\text { green chimeric } \\
\text { mutants }\end{array}$ & CRISPR/Cas9 & A. tumefaciens & $\begin{array}{l}\text { Tissue culture } \\
\text { seedling scales }\end{array}$ & Yan et al. 2019 \\
\hline $\begin{array}{l}\text { Petunia hybrida } \\
\text { 'Madness' }\end{array}$ & $P h N$ & $\begin{array}{l}\text { Site-directed } \\
\text { mutagenesis in } \\
\text { NR genes }\end{array}$ & CRISPR/Cas9 & $\begin{array}{l}\text { PEG-mediated } \\
\text { transfection of } \\
\text { RNP }\end{array}$ & Leaf protoplasts & Subburaj et al. 2016 \\
\hline $\begin{array}{l}\text { P. hybrida inbred } \\
\text { line Mitchell } \\
\text { Diploid }\end{array}$ & $P h P D S$ & $\begin{array}{l}\text { Albino and mosaic } \\
\text { shoots }\end{array}$ & CRISPR/Cas9 & A. tumefaciens & Young leaf & $\begin{array}{l}\text { Zhang et al. 2016a, } \\
\text { b, c }\end{array}$ \\
\hline $\begin{array}{l}\text { Petunia 'Mirage } \\
\text { Rose' }\end{array}$ & PhACO1 & $\begin{array}{l}\text { Reduced ethylene } \\
\text { production and } \\
\text { enhanced flower } \\
\text { longevity }\end{array}$ & CRISPR/Cas9 & A. tumefaciens & Leaf explants & Xu et al. 2020 \\
\hline P. inflata & PiSSK1 & $\begin{array}{l}\text { RNase-based self- } \\
\text { incompatibility }\end{array}$ & CRISPR/Cas9 & A. tumefaciens & Leaf disks & Sun and Kao 2018 \\
\hline $\begin{array}{l}\text { Phalaenopsis } \\
\text { equestris }\end{array}$ & $\begin{array}{l}\text { MADS44, } \\
\text { MADS } 36, \\
\text { MADS8 }\end{array}$ & $\begin{array}{l}\text { MADS-null } \\
\text { mutants }\end{array}$ & CRISPR/Cas9 & A. tumefaciens & $\begin{array}{l}\text { One-month-old } \\
\text { protocorms }\end{array}$ & Tong et al. 2020 \\
\hline $\begin{array}{l}\text { Torenia fournieri } \\
\text { 'Crown Violet' }\end{array}$ & $F 3 H$ & $\begin{array}{l}\text { Flower colour } \\
\text { changes }\end{array}$ & CRISPR/Cas9 & A. tumefaciens & Leaf sections & $\begin{array}{l}\text { Nishihara et al. } \\
2018\end{array}$ \\
\hline T. fournieri & $T f R A D 1$ & $\begin{array}{l}\text { Flowers with } \\
\text { abnormal shape } \\
\text { and pigmentation }\end{array}$ & CRISPR/Cas9 & A. tumefaciens & Leaf sections & Su et al. 2017 \\
\hline
\end{tabular}

or heterozygous biallelic mutations, an important result considering the high heterozygosity and long juvenility of orchid species.

P. hybrida mutant lines with extended flower longevity were obtained by editing the $A C O 1$ gene, encoding the ethylene biosynthesis enzyme 1-aminocyclopropane-1-carboxylate oxidase (Xu et al. 2020). Transient assays were preliminarily carried out by transfecting leaf protoplasts with RNPs targeting $A C O 1$, while the regeneration of edited plants was then achieved by Agrobacterium-mediated transformation. The mutation frequency was equal to $31.5 \%: 2.5,15.0$ and
$82.5 \%$ of mutants were biallelic homozygous, monoallelic and chimaeric, respectively. Both in $\mathrm{T}_{0}$ and $\mathrm{T}_{1}$ generations, homozygous plants showed lower ethylene production and higher flower longevity than monoallelic ones. Compared to the wild type, no other changes could be observed in flowers of the mutants. Interestingly, no off-target mutations were induced in paralogous genes $\mathrm{ACO} 3$ and $\mathrm{ACO} 4$, which show six and seven mismatches, respectively, with $A C O 1$. The gene encoding the transcription factor EPHEMERAL1 (EPH1) has been recently silenced using CRISPR/Cas9 in I. nil. Biallelic $\mathrm{T}_{1}$ mutant plants, in some cases T-DNA free, 
showed a delayed wilting of flowers (20.6-23.3 h against $12.8 \mathrm{~h}$ in wild type plants) (Shibuya et al. 2018).

CRISPR/Cas9-mediated genome editing was also applied to reduce the content of lignocellulose in the orchid Dendrobium officinale. Five genes participating to the lignocellulose biosynthesis pathway were selected: Coumarate 3-Hydroxylase $(\mathrm{C} 3 \mathrm{H})$, Cinnamate 4-Hydroxylase $(\mathrm{C} 4 \mathrm{H})$, 4-Coumarate:Coenzyme A Ligase (4CL), Cinnamoyl Coenzyme A Reductase (CCR) and Irregular Xylem5 (IRX). Mutation rate varied between 10 and $100 \%$ comprising nucleotide insertions, deletions and substitutions (Kui et al. 2017).

Finally, in the self-incompatible species Petunia inflata, the PiSSK1 gene, encoding the Skp1 subunit of the SCFSLF complex, was knocked-out by CRISPR/Cas 9 to examine the effect of a complete absence of PiSSK1 in pollen on SI behavior (Sun and Kao 2018).

\section{Conclusions and perspectives}

Fast and precise site-directed approaches for modifying or inserting genes of interest in higher plants is a long-sought goal (Cardi and Stewart 2016). Conventional breeding methods based on hybridization and recombination, or on random mutagenesis, are often long, unprecise and unpredictable. Transformation approaches based on illegitimate recombination between non-homologous sequences result in random insertion with possible interruption of endogenous coding sequences and erratic expression of transferred genes. Genome editing relying on the use of chimaeric nucleases able to induce DSBs in DNA, and among them particularly the CRISPR/Cas technology (Jinek et al. 2012), revolutionized this field both for functional genomics studies and applied plant breeding. NHEJ-mediated approaches are relatively simple and are generally used to induce random mutations (usually small indels) in a preselected site. On the other hand, HDR-mediated approaches can be used to replace either a predefined single nucleotide or an entire gene sequence using a template, but their efficiency in higher plants is usually much lower. Recent technological developments, however, leading to base editing and prime editing approaches, might allow the precise editing of one or more bases without DNA DSBs and repair template (Platt 2019). Furthermore, CRISPR/Cas9-based approaches can be used to regulate gene expression by altering the sequence of cisregulatory elements or fusing transcriptional repressors/ activators to editing constructs that include a catalytically inactive dCas9 and sgRNAs targeting specific promoter sequences (Zhang et al. 2018).

The use of genome editing approaches is particularly desirable in ornamental species, which are often characterized by high heterozygosity, large genomes, high chromosome number, polyploidy, long life-cycle, self-sterility or inability to produce seeds, limiting the applicability of conventional breeding approaches. In particular, the development of DNA-free editing methods would be particularly welcome to obtain no-transgenic first-generation edited plants. To achieve that, several methods have been developed in other species (Woo et al. 2015; Zhang et al. 2016c; Chen et al. 2018), but no applications have been shown in ornamental species, except for the few examples in petunia described above. Furthermore, especially cut flowers species demand a high degree of novelty and usually have a high turn-over of varieties, requiring fast methods for continuous breeding of novel genotypes. To implement such novel approaches in ornamental species, however, extensive knowledge of genomes and genes organization and function, and efficient transformation/regeneration protocols, are required.

As previously reported in this review, capitalizing on knowledge derived from studies in model species, homologues to genes controlling main traits in cut flower species, namely flowering induction and flower development, colour, scent and longevity, have been isolated and their function investigated in detail. Due to the relatively higher number of sequence and functional information available, and also to commercial impact, it is likely that most applications in the short-medium term will aim to edit genes controlling the colour of flowers. Genome and/or trascriptome sequences are now available in several ornamentals. For some species with untractable genome sizes, e.g. the hexaploid $C$. morifolium, some helpful information could come from the genome of the related diploid wild relative $C$. seticuspe, although also the latter has a rather large genome. Sequences as such, however, are not sufficient to implement genome editing approaches in plant breeding, being functional studies necessary to find out genotype-to-phenotype relationships. Recently, an extensive study performing transcriptomic and functional analyses allowed to identify a high number of candidate genes involved in the development of elaborate petals and specialized characters in $N$. damascena, opening the way for similar investigations in other species with complex flowers (Zhang et al. 2020). Information derived from comparative genomics aiming to mine variation in varieties and related (sub)species, when available, could also allow the discovery of novel alleles and SNPs that can be further investigated in association studies. Such variation can be validated and finally exploited by genome editing in target genotypes.

In various ornamental species, the efficiency and applicability of in vitro culture techniques are limited by highly variable and genotype-dependent responses, with many recalcitrant cultivars, and by the reduced research efforts and investments. Studies on some ornamentals such as Petunia, Phalaenopsis and Torenia, which are relatively easy to transform, helped carry out proof-of-concept 
studies aiming to develop novel technologies and acquire information on genetics and molecular biology underpinning traits of interest. Nonetheless, interesting results were recently produced also in less amenable species, as, for instance, Lilium and Ipomoea. The improvement of the efficiency of in vitro protocols can be attempted by empirical experimentation regarding culture parameters, but that is a long process and results are often genotype dependent. Recently, however, genetic and epigenetic mechanisms controlling regeneration in vitro have been investigated in some (not necessarily ornamental) species, to transfer responsible genes and manipulate their expression in recalcitrant genotypes (Cardi et al. 2017). Specific plant and bacterial proteins could also be engineered to improve Agrobacterium-mediated transformation (Gelvin 2003; Altpeter et al. 2016). Otherwise, for recalcitrant genotypes, the development of transformation protocols not depending on in vitro culture and regeneration of explants should be attempted (Altpeter et al. 2016). Lately, transcription factors acting as morphogenic regulators in a number of species (e.g. WUSCHEL, BABY BOOM and others) were demonstrated to be able to promote regeneration and transformation both in vitro and in planta, also for the delivery of editing reagents (Jha et al. 2020; Maher et al. 2020; Ji et al. 2020). Like other recalcitrant crops, ornamental species not amenable to tissue culture techniques could benefit from these findings.

Relatively few, but promising, examples of genome editing applications are now available in ornamentals, at least concerning NHEJ-mediated targeted mutagenesis. In several cases, biallelic mutations affecting commercially important traits have been obtained in the first generation of regenerated plants. That is particularly important in highly heterozygous and/or perennial species. Remarkably, no off-target mutations have been induced in all cases where that was investigated, e.g. in ipomoea and petunia. In polyploid species, such as chrysanthemum, it has been indirectly shown that it should be possible to mutate multiple copies of a target gene, as demonstrated in other polyploids, e.g. hexaploid wheat (Wang et al. 2014). In petunia, the DNA-free editing of a target gene was obtained delivering preassembled sgRNA-Cas9 ribonucleoproteins to protoplasts. Albeit the possibility to do that also in other ornamentals is highly desirable, considering the impossibility to sort out unwanted sequences by genetic segregation in many cases, practically it will not be possible until transfection methods based on protoplasts or, alternatively, biolistics (Svitashev et al. 2016) will be available.

The commercial exploitation of genome editing products and their public acceptance, however, will depend on proportionate, and hopefully world-wide consistent, regulatory frame as well as correct information (Custers 2017; Parry and Jose 2018; Eriksson et al. 2019; Herman et al. 2019).
Acknowledgements Authors thank Dr. Fiorenzo Gimelli, Centro Servizi per la Floricoltura, Liguria region, for kindly providing data on the value of global floriculture production and floriculture market, and Dr. Barbara Ruffoni, CREA Research Centre for Vegetable and Ornamental Plants, Sanremo, for the critical reading of the manuscript. The funding support of the Italian Ministry of Agriculture (MiPAAF), Project "Biotech", is acknowledged.

Author contributions statement All authors conceived the content of the review, contributed to data collection and text writing, read and approved the manuscript.

\section{Compliance with ethical standards}

Conflict of interest Authors declare that they have no conflict of interest.

\section{References}

Abbas F, Ke Y, Yu R et al (2017) Volatile terpenoids: multiple functions, biosynthesis, modulation and manipulation by genetic engineering. Planta 246:803-816. https://doi.org/10.1007/s0042 5-017-2749-X

Abbas F, Ke Y, Yu R, Fan Y (2019) Functional characterization and expression analysis of two terpene synthases involved in floral scent formation in Lilium "Siberia." Planta 249:71-93. https:// doi.org/10.1007/s00425-018-3006-7

Adal AM, Sarker LS, Malli RPN et al (2019) RNA-Seq in the discovery of a sparsely expressed scent-determining monoterpene synthase in lavender (Lavandula). Planta 249:271-290. https:// doi.org/10.1007/s00425-018-2935-5

Ahn CH, Ramya M, An HR et al (2020) Progress and challenges in the improvement of ornamental plants by genome editing. Plants 9:687. https://doi.org/10.3390/plants9060687

Altpeter F, Springer NM, Bartley LE et al (2016) Advancing crop transformation in the era of genome editing. Plant Cell 28:1510-1520. https://doi.org/10.1105/tpc.16.00196

Andrés F, Coupland G (2012) The genetic basis of flowering responses to seasonal cues. Nat Rev Genet 13:627-639. https://doi. org/10.1038/nrg3291

Aragão FJL, Cid LPB (2006) Genetic engineering in floricultural plants. In: Teixeira da Silva JA (ed) Floriculture, ornamental and plant biotechnology. Global Science Books, London, pp 1-8

Badouin H, Gouzy J, Grassa CJ et al (2017) The sunflower genome provides insights into oil metabolism, flowering and Asterid evolution. Nature 546:148-152. https://doi.org/10.1038/nature22380

Baudino S, Sun P, Caissard JC et al (2019) Rose floral scent. Acta Hortic 1232:69-80. https://doi.org/10.17660/ActaHortic .2019.1232.12

Boase MR, Lewis DH, Davies KM et al (2010) Isolation and antisense suppression of flavonoid 3', 5'-hydroxylasemodifies flower pigments and colour in cyclamen. BMC Plant Biol 10:107. https:// doi.org/10.1186/1471-2229-10-107

Bombarely A, Moser M, Amrad A et al (2016) Insight into the evolution of the Solanaceae from the parental genomes of Petunia hybrida. Nat Plants 2:1-9. https://doi.org/10.1038/nplan ts. 2016.74

Boutigny AL, Dohin N, Pornin D, Rolland M (2020) Overview and detectability of the genetic modifications in ornamental plants. Hortic Res 7:11. https://doi.org/10.1038/s41438-019-0232-5

Boxriker M, Boehm R, Möhring J, Piepho H-P (2017) Efficient statistical design in two-phase experiments on vase life in carnations 
(Dianthus caryophyllus L.). Postharvest Biol Technol 128:161168. https://doi.org/10.1016/j.postharvbio.2016.12.003

Cai J, Liu X, Vanneste K et al (2015) The genome sequence of the orchid Phalaenopsis equestris. Nat Genet 47:65-72. https://doi. org/10.1038/ng.3149

Cardi T, Stewart CN (2016) Progress of targeted genome modification approaches in higher plants. Plant Cell Rep 35:1401-1416. https ://doi.org/10.1007/s00299-016-1975-1

Cardi T, D’Agostino N, Tripodi P (2017) Genetic transformation and genomic resources for next-generation precise genome engineering in vegetable crops. Front Plant Sci 8:241. https://doi. org/10.3389/fpls.2017.00241

Chan WS, Abdullah JO, Namasivayam P, Mahmood M (2009) Molecular characterization of a new 1-deoxy-d-xylulose 5-phosphate reductoisomerase (DXR) transcript from Vanda Mimi Palmer. Sci Hortic 121:378-382. https://doi.org/10.1016/j.scien ta.2009.02.015

Chan WS, Abdullah JO, Namasivayam P (2011) Isolation, cloning and characterization of fragrance-related transcripts from Vanda Mimi Palmer. Sci Hortic 127:388-397. https://doi.org/10.1016/j. scienta.2010.09.024

Chandler SF (2007) Practical lessons in the commercialization of genetically modified plants-Long vase-life carnation. Acta Hortic 764:71-82. https://doi.org/10.17660/ActaHortic.2007.764.8

Chandler SF, Brugliera F (2011) Genetic modification in floriculture. Biotechnol Lett 33:207-214. https://doi.org/10.1007/s1052 9-010-0424-4

Chandler SF, Sanchez C (2012) Genetic modification; the development of transgenic ornamental plant varieties. Plant Biotechnol J 10:891-903. https://doi.org/10.1111/j.1467-7652.2012.00693.x

Chang W, Guo Y, Zang H, Liu X, Guo L (2020) Same actor in different stages: genes in shoot apical meristem maintenance and floral meristem determinacy in Arabidopsis. Front Ecol Evol 8:89. https://doi.org/10.3389/fevo.2020.00089

Chao YT, Yen SH, Yeh JH, et al (2017) Orchidstra 2.0-A Transcriptomics Resource for the Orchid Family. Plant Cell Physiol 581:e9. https://doi.org/10.1093/pcp/pcw220

Chao YT, Chen WC, Chen CY et al (2018) Chromosome-level assembly, genetic and physical mapping of Phalaenopsis aphrodite genome provides new insights into species adaptation and resources for orchid breeding. Plant Biotechnol J 16:2027-2041. https://doi.org/10.1111/pbi.12936

Chen L, Li W, Katin-Grazzini L et al (2018) A method for the production and expedient screening of CRISPR/Cas9-mediated nontransgenic mutant plants. Hortic Res 5:3. https://doi.org/10.1038/ s41438-018-0023-4

Chuang YC, Lee MC, Chang YL et al (2017) Diurnal regulation of the floral scent emission by light and circadian rhythm in the Phalaenopsis orchids. Bot Stud 58:50. https://doi.org/10.1186/ s40529-017-0204-8

Clevenger DJ, Barrett JE, Klee HJ, Clark DG (2004) Factors affecting seed production in transgenic ethylene-insensitive petunias. J Am Soc Hortic Sci 129:401-406. https://doi.org/10.21273/jashs 129.3.0401

Coen ES, Meyerowitz EM (1991) The war of the whorls: genetic interactions controlling flower development. Nature 353:31-37. https ://doi.org/10.1038/353031a0

Coen ES, Romero JM, Doyle S et al (1990) Floricaula: a homeotic gene required for flower development in Antirrhinum majus. Cell 63:1311-1322. https://doi.org/10.1016/0092-8674(90)90426-f

Custers R (2017) The regulatory status of gene-edited agricultural products in the EU and beyond. Emerg Top Life Sci 1:221-229. https://doi.org/10.1042/ETLS20170019

Dennis L, Peacock J (2019) Genes directing flower development in Arabidopsis. Plant Cell 31:1192-1193
Ding L, Zhao K, Zhang X et al (2019) Comprehensive characterization of a floral mutant reveals the mechanism of hooked petal morphogenesis in Chrysanthemum morifolium. Plant Biotechnol J 17:2325-2340. https://doi.org/10.1111/pbi.13143

Ding L, Song A, Zhang X et al (2020) The core regulatory networks and hub genes regulating flower development in Chrysanthemum morifolium. Plant Mol Biol 103:669-688. https://doi. org/10.1007/s11103-020-01017-8

Dong AX, Xin HB, Li ZJ et al (2018) High-quality assembly of the reference genome for scarlet sage, Salvia splendens, an economically important ornamental plant. Gigascience 7:1-10. https:// doi.org/10.1093/gigascience/giy068

Du F, Wang T, Fan J et al (2019) Volatile composition and classification of Lilium flower aroma types and identification, polymorphisms, and alternative splicing of their monoterpene synthase genes. Hortic Res 6:110. https://doi.org/10.1038/s41438-019-0192-9

Dunkel M, Schmidt U, Struck S et al (2009) SuperScent-a database of flavors and scents. Nucleic Acids Res 37(Sup. 1):D291-D294. https://doi.org/10.1093/nar/gkn695

Duradeva N (2002) Molecular control of floral fragrance. In: Vainstein A (ed) Breeding for ornamentals: classical and molecular approaches. Springer, Dordrecht, pp 295-309. https://doi. org/10.1007/978-94-017-0956-9_15

Durbin ML, Lundy KE, Morrell PL, Torres-Martinez CL, Clegg MT (2003) Genes that determine flower color: the role of regulatory changes in the evolution of phenotypic adaptations. Mol Phylogenet Evol 29:507-518. https://doi.org/10.1016/S1055 -7903(03)00196-9

Eriksson D, Kershen D, Nepomuceno A et al (2019) A comparison of the EU regulatory approach to directed mutagenesis with that of other jurisdictions, consequences for international trade and potential steps forward. New Phytol 222:1673-1684. https://doi. org/10.1111/nph.15627

Fan Z, Li J, Li X, Yin H (2019) Composition analysis of floral scent within genus Camellia uncovers substantial interspecific variations. Sci Hortic 250:207-213. https://doi.org/10.1016/j.scien ta.2019.02.050

Filiault DL, Ballerini ES, Mandáková T et al (2018) The Aquilegia genome provides insight into adaptive radiation and reveals an extraordinarily polymorphic chromosome with a unique history. Elife 7:e36426. https://doi.org/10.7554/eLife.36426

Gao Y, Gao Y, Fan M et al (2017) Overexpression of Chrysanthemum morifolium SVP gene delays blossoming and regulates inflorescence architecture in transgenic Arabidopsis. Can J Plant Sci 97:1130-1139. https://doi.org/10.1139/cjps-2017-0007

Gattolin S, Cirilli M, Chessa S et al (2020) Mutations in orthologous PETALOSA TOE-type genes cause dominant double-flower phenotype in phylogenetically distant eudicots. J Exp Bot 71:25852595. https://doi.org/10.1093/jxb/eraa032/5710789

Gelvin SB (2003) Improving plant genetic engineering by manipulating the host. Trends Biotechnol 21:95-98. https://doi.org/10.1016/ S0167-7799(03)00005-2

Grotewold E (2006) The genetics and biochemistry of floral pigments. Annu Rev Plant Biol 57:761-780. https://doi.org/10.1146/annur ev.arplant.57.032905.105248

Guo X, Yu C, Luo L et al (2018) Developmental transcriptome analysis of floral transition in Rosa odorata var. gigantea. Plant Mol Biol 97:113-130. https://doi.org/10.1007/s11103-018-0727-8

Gupta AK, Schauvinhold I, Pichersky E, Schiestl FP (2014) Eugenol synthase genes in floral scent variation in Gymnadenia species. Funct Integr Genomics 14:779-788. https://doi.org/10.1007/ s10142-014-0397-9

Gustafson-Brown C, Savidge B, Yanofsky MF (1994) Regulation of the Arabidopsis floral homeotic gene APETALA1. Cell 76:131-143. https://doi.org/10.1016/0092-8674(94)90178-3 
Guterman I, Shalit M, Menda N et al (2002) Rose scent: genomics approach to discovering novel floral fragrance-related genes. Plant Cell 14:2325-2338. https://doi.org/10.1105/tpc.005207

Hahne G, Tomlinson L, Nogué F (2019) Precision genetic engineering tools for next-generation plant breeding. Plant Cell Rep 38:435436. https://doi.org/10.1007/s00299-019-02400-6

Herman RA, Fedorova M, Storer NP (2019) Will following the regulatory script for GMOs promote public acceptance of geneedited crops? Trends Biotechnol 37:1272-1273. https://doi. org/10.1016/j.tibtech.2019.06.007

Hilscher J, Bürstmayr H, Stoger E (2017) Targeted modification of plant genomes for precision crop breeding. Biotechnol $\mathrm{J}$ 12:1600173. https://doi.org/10.1002/biot.201600173

Hirakawa H, Sumitomo K, Hisamatsu T et al (2019) De novo wholegenome assembly in Chrysanthemum seticuspe, a model species of Chrysanthemums, and its application to genetic and gene discovery analysis. DNA Res 26:195-203. https://doi.org/10.1093/ dnares/dsy048

Hong Y, Jackson S (2015) Floral induction and flower formation-the role and potential applications of miRNAs. Plant Biotechnol $\mathbf{J}$ 13:282-292. https://doi.org/10.1111/pbi.12340

Hoshino A, Jayakumar V, Nitasaka E et al (2016) Genome sequence and analysis of the Japanese morning glory Ipomoea nil. Nat Commun 7:1-10. https://doi.org/10.1038/ncomms13295

Hsiao YY, Tsai WC, Kuoh CS et al (2006) Comparison of transcripts in Phalaenopsis bellina and Phalaenopsis equestris (Orchidaceae) flowers to deduce monoterpene biosynthesis pathway. BMC Plant Biol 6:14. https://doi.org/10.1186/1471-2229-6-14

Hsiao YY, Jeng MF, Tsai WC et al (2008) A novel homodimeric geranyl diphosphate synthase from the orchid Phalaenopsis bellina lacking a $\mathrm{DD}(\mathrm{X}) 2-4 \mathrm{D}$ motif. Plant J 55:719-733. https://doi. org/10.1111/j.1365-313X.2008.03547.x

Hsu CC, Chen HH (2017) Flower color and pigmentation patterns in Phalaenopsis orchids. Orchid Biotechnol III:393-420. https:// doi.org/10.1142/9789813109223_0019

Hu Z, Zhang H, Leng P et al (2013) The emission of floral scent from Lilium "Siberia" in response to light intensity and temperature. Acta Physiol Plant 35:1691-1700. https://doi.org/10.1007/s1173 8-012-1211-8

Hu Z, Tang B, Wu Q et al (2017) Transcriptome sequencing analysis reveals a difference in monoterpene biosynthesis between scented Lilium "Siberia" and unscented Lilium "Novano." Front Plant Sci 8:1351. https://doi.org/10.3389/fpls.2017.01351

Huang M, Fan R, Ye X, Lin R, Luo Y, Fang N, Zhong H, Chen S (2018) The transcriptome of flower development provides insight into floral scent formation in Freesia hybrida. Plant Growth Regul 86(1):93-104. https://doi.org/10.1007/s10725-018-0413-5

Jack T (2004) Molecular and genetic mechanisms of floral control. Plant Cell 16(Suppl):S1-17. https://doi.org/10.1105/tpc.017038

Jha RK, Udupa S, Rai AK et al (2020) Conditional down-regulation of GreA impacts expression of rRNA and transcription factors, affecting Mycobacterium smegmatis survival. Sci Rep 10:5802. https://doi.org/10.1038/s41598-020-62703-7

Ji X, Yang B, Wang D (2020) Achieving plant genome editing while bypassing tissue culture. Trends Plant Sci 25:427-429. https:// doi.org/10.1016/j.tplants.2020.02.011

Jinek M, Chylinski K, Fonfara I et al (2012) A programmable dualRNA-guided DNA endonuclease in adaptive bacterial immunity. Science 337:816-821. https://doi.org/10.1126/science.1225829

Katsumoto Y, Fukuchi-Mizutani M, Fukui Y et al (2007) Engineering of the Rose flavonoid biosynthetic pathway successfully generated blue-hued flowers accumulating delphinidin. Plant Cell Physiol 48:1589-1600. https://doi.org/10.1093/pcp/pcm131

Kellner F, Kim J, Clavijo BJ et al (2015) Genome-guided investigation of plant natural product biosynthesis. Plant J 82:680-692. https ://doi.org/10.1111/tpj.12827
Kim J, Park JH, Lim CJ et al (2012) Small RNA and transcriptome deep sequencing proffers insight into floral gene regulation in Rosa cultivars. BMC Genomics 13:657. https://doi. org/10.1186/1471-2164-13-657

Kim YM, Kim S, Koo N et al (2017) Genome analysis of Hibiscus syriacus provides insights of polyploidization and indeterminate flowering in woody plants. DNA Res 24:71-80. https://doi. org/10.1093/dnares/dsw049

Kingsbury N (2009) Hybrid: the history and science of plant breeding. University of Chicago Press, Chicago. https://doi.org/10.7208/ chicago/9780226437057.001.0001

Kishi-Kaboshi M, Aida R, Sasaki K (2017) Generation of gene-edited Chrysanthemum morifolium using multicopy transgenes as targets and markers. Plant Cell Physiol 58:216-226. https://doi. org/10.1093/pcp/pcw222

Kishi-Kaboshi M, Aida R, Sasaki K (2018) Genome engineering in ornamental plants: current status and future prospects. Plant Physiol Biochem 131:47-52. https://doi.org/10.1016/j.plaph y.2018.03015

Knudsen JT, Eriksson R, Gershenzon J, Ståhl B (2006) Diversity and distribution of floral scent. Bot Rev 72:1-120

Komiya R, Ikegami A, Tamaki S et al (2008) Hd3a and RFT1 are essential for flowering in rice. Development 135:767-774. https ://doi.org/10.1242/dev.008631

Koseki M, Goto K, Masuta C, Kanazawa A (2005) The star-type color pattern in Petunia hybrida 'Red Star' flowers is induced by sequence-specific degradation of Chalcone synthase RNA. Plant Cell Physiol 46:1879-1883. https://doi.org/10.1093/pcp/pci192

Krizek BA, Fletcher JC (2005) Molecular mechanisms of flower development: an armchair guide. Nat Rev Genet 6:688-698. https:// doi.org/10.1038/nrg1675

Kui L, Chen H, Zhang W et al (2017) Building a genetic manipulation tool box for orchid biology: identification of constitutive promoters and application of CRISPR/Cas9 in the orchid Dendrobium officinale. Front Plant Sci 7:2036. https://doi.org/10.3389/ fpls.2016.02036

Kumari P, Panwar S, Soni A (2017) Biosynthesis, composition and sources of floral scent in ornamental crops: a review. Chem Sci Rev Lett 6:1502-1509

Leeggangers HACF, Rosilio-Brami T, Bigas-Nadal J et al (2018) Tulipa gesneriana and Lilium longiflorum PEBP genes and their putative roles in flowering time control. Plant Cell Physiol 59:90106. https://doi.org/10.1093/pcp/pcx164

Li X, Bian H, Song D et al (2013) Flowering time control in ornamental gloxinia (Sinningia speciosa) by manipulation of miR159 expression. Ann Bot 111:791-799. https://doi.org/10.1093/aob/ mct034

Li M, Zhang D, Gao Q et al (2019) Genome structure and evolution of Antirrhinum majus L. Nat Plants 5:174-183. https://doi. org/10.1038/s41477-018-0349-9

Li XY, Guo F, Ma SY et al (2019) Regulation of flowering time via miR172-mediated APETALA2-like expression in ornamental gloxinia (Sinningia speciosa). J Zhejiang Univ Sci B 20:322331. https://doi.org/10.1631/jzus.B1800003

Liu H, Sun M, Du D et al (2016) Whole-transcriptome analysis of differentially expressed genes in the ray florets and disc florets of Chrysanthemum morifolium. BMC Genomics 17:398. https://doi. org/10.1186/s12864-016-2733-Z

Liu J, Fu X, Dong Y et al (2018) MIKCC-type MADS-box genes in Rosa chinensis: The remarkable expansion of ABCDE model genes and their roles in floral organogenesis. Hortic Res 5:1-15. https://doi.org/10.1038/s41438-018-0031-4

Lu M, An H, Li L (2016) Genome survey sequencing for the characterization of the genetic background of Rosa roxburghii Tratt and leaf ascorbate metabolism genes. PLoS ONE 11:e0147530. https ://doi.org/10.1371/journal.pone.0147530 
Magnard JL, Roccia A, Caissard JC et al (2015) Plant volatiles. Biosynthesis of monoterpene scent compounds in roses. Science 349:81-83. https://doi.org/10.1126/science.aab0696

Magnard JL, Bony AR, Bettini F et al (2018) Linalool and linalool nerolidol synthases in roses, several genes for little scent. Plant Physiol Biochem PPB 127:74-87. https://doi.org/10.1016/j.plaph y.2018.03.009

Maher MF, Nasti RA, Vollbrecht M et al (2020) Plant gene editing through de novo induction of meristems. Nat Biotechnol 38:8489. https://doi.org/10.1038/s41587-019-0337-2

Meyerowitz EM (1989) Arabidopsis, a useful weed. Cell 56:263-269. https://doi.org/10.1016/0092-8674(89)90900-8

Mitsuda N, Matsui K, Ikeda M, Nakata M, Oshima Y, Nagatoshi Y, Ohme-Takagi M (2011) CRES-T, an effective gene silencing system utilizing chimeric repressors. Methods Mol Biol 754:87105. https://doi.org/10.1007/978-1-61779-154-3_5

Muhlemann JK, Klempien A, Dudareva N (2014) Floral volatiles: from biosynthesis to function. Plant Cell Environ 37:1936-1949. https ://doi.org/10.1111/pce.12314

Naing AH, Kim CK (2018) Roles of R2R3-MYB transcription factors in transcriptional regulation of anthocyanin biosynthesis in horticultural plants. Plant Mol Biol 98:1-18. https://doi.org/10.1007/ s11103-018-0771-4

Nakamura N, Hirakawa H, Sato S et al (2018) Genome structure of Rosa multiflora, a wild ancestor of cultivated roses. DNA Res 25:113-121. https://doi.org/10.1093/dnares/dsx042

Nakatsuka T, Mishiba K-i, Abe Y, Kubota A, Kakizaki Y, Yamamura S, Nishihara M (2008) Flower color modification of gentian plants by RNAi-mediated gene silencing. Plant Biotechnol 25:61-68. https://doi.org/10.5511/plantbiotechnology.25.61

Netam N (2018) Improving ornamental's vase life through molecular approaches: a review. J Pharmacogn Phytochem 7:1687-1691

$\mathrm{Ng}$ J, Smith SD (2016) How to make a red flower: the combinatorial effect of pigments. AoB Plants 8:plw013. https://doi.org/10.1093/ aobpla/plw013

Nisar N, Li L, Lu S, Khin NC, Pogson BJ (2015) Carotenoid metabolism in plants. Mol Plant 8:68-82. https://doi.org/10.1016/j. molp.2014.12.007

Nishihara M, Nakatsuka T, Yamamura S (2005) Flavonoid components and flower color change in transgenic tobacco plants by suppression of chalcone isomerase gene. FEBS Lett 579:6074-6078. https://doi.org/10.1016/j.febslet.2005.09.073

Nishihara M, Higuchi A, Watanabe A, Tasaki K (2018) Application of the CRISPR/Cas9 system for modification of flower color in Torenia fournieri. BMC Plant Biol 18:1-9. https://doi. org/10.1186/s12870-018-1539-3

Noda N (2018) Recent advances in the research and development of blue flowers. Breed Sci 68:79-87. https://doi.org/10.1270/jsbbs .17132

Nowak MD, Russo G, Schlapbach R et al (2015) The draft genome of Primula veris yields insights into the molecular basis of heterostyly. Genome Biol 16:12. https://doi.org/10.1186/s1305 9-014-0567-z

Ohmiya A (2018) Molecular mechanisms underlying the diverse array of petal colors in chrysanthemum flowers. Breed Sci 681:119127. https://doi.org/10.1270/jsbbs. 17075

Olsen A, Lütken H, Hegelund JN, Müller R (2015) Ethylene resistance in flowering ornamental plants. Improvements and future perspectives. Hortic Res 2:15038. https://doi.org/10.1038/hortr es.2015.38

Onozaki T, Yagi M, Tanase K, Shibata M (2011) Crossings and selections for six generations based on flower vase life to create lines with ethylene resistance or ultra-long vase life in carnations (Dianthus caryophyllus L.). J Japanese Soc Hortic Sci 80:486498. https://doi.org/10.2503/jjshs1.80.486
Parry G, Jose S (2018) Separate product from process: framing the debate that surrounds the potential uptake of new breeding technologies. Physiol Plant 164:372-377. https://doi.org/10.1111/ ppl. 12680

Pei H, Ma N, Tian J et al (2013) An NAC transcription factor controls ethylene-regulated cell expansion in flower petals. Plant Physiol 163:775-791. https://doi.org/10.1104/pp.113.223388

Platt RJ (2019) CRISPR tool enables precise genome editing. Nature 576:48-49. https://doi.org/10.1038/d41586-019-03392-9

Ramya M, Jang S, An HR et al (2020) Volatile organic compounds from orchids: from synthesis and function to gene regulation. Int J Mol Sci 21:1160. https://doi.org/10.3390/ijms21031160

Rosati C, Simoneau P (2006) Metabolie engineering of flower color in ornamental plants. J Crop Improv 18:301-324. https://doi. org/10.1300/J411v18n01_01

Rubio-Somoza I, Weigel D (2011) MicroRNA networks and developmental plasticity in plants. Trends Plant Sci 6:258-264. https:// doi.org/10.1016/j.tplants.2011.03.001

Sablowski R (2010) Genes and functions controlled by floral organ identity genes. Semin Cell Dev Biol 21:94-99. https://doi. org/10.1016/j.semcdb.2009.08.008

Sagawa JM, Le S, LaFountain AM, Frank HA, Liu C, Yuan YW (2016) An R2R3-MYB transcription factor regulates carotenoidpigmentation in Mimulus lewisiiflowers. New Phytol 209:1049-1057. https://doi.org/10.1111/nph.13647

Saint-Oyant LH, Ruttink T, Hamama L et al (2018) A high-quality genome sequence of Rosa chinensis to elucidate ornamental traits. Nat Plants 4:473-484. https://doi.org/10.1038/s4147 7-018-0166-1

Sasaki K, Ohtsubo N (2020) Production of multi-petaled Torenia fournieri flowers by functional disruption of two class-C MADSbox genes. Planta 251:1-16. https://doi.org/10.1007/s00425-02003393-3

Savin KW, Baudinette SC, Graham MW et al (2019) Antisense ACC oxidase rna delays carnation petal senescence. HortScience 30:970-972. https://doi.org/10.21273/hortsci.30.5.970

Seitz C, Vitten M, Steinbach P et al (2007) Redirection of anthocyanin synthesis in Osteospermum hybrida by a two-enzyme manipulation strategy. Phytochemistry 68(6):824-833. https://doi. org/10.1016/j.phytochem.2006.12.012

Shahin A, van Kaauwen M, Esselink D et al (2012) Generation and analysis of expressed sequence tags in the extreme large genomes Lilium and Tulipa. BMC Genomics 13:640. https://doi. org/10.1186/1471-2164-13-640

Sheng L, Xia W, Zang S et al (2018) Transcriptome-sequencing analyses reveal putative genes related to flower color variation in Chinese Rosa rugosa. Acta Physiol Plant 40:62. https://doi. org/10.1007/s11738-018-2635-6

Shibuya K, Barry KG, Ciardi JA et al (2004) The central role of PhEIN2 in ethylene responses throughout plant development in petunia. Plant Physiol 136:2900-2912. https://doi.org/10.1104/ pp.104.046979

Shibuya K, Shimizu K, Niki T, Ichimura K (2014) Identification of a NAC transcription factor, EPHEMERAL1, that controls petal senescence in Japanese morning glory. Plant J 79:1044-1051. https://doi.org/10.1111/tpj.12605

Shibuya K, Watanabe K, Ono M (2018) CRISP/Cas9-mediated mutagenesis of the EPHEMERAL1 locus that regulates petal senescence in Japanese morning glory. Plant Physiol 131:53-57. https://doi.org/10.1016/j.plaphy.2018.04.036

Smulders MJM, Arens P, Bourke PM et al (2019) In the name of the rose: a roadmap for rose research in the genome era. Hortic Res 6:65. https://doi.org/10.1038/s41438-019-0156-0

Soltis DE, Ma H, Frohlich MW et al (2007) The floral genome: an evolutionary history of gene duplication and shifting patterns 
of gene expression. Trends Plant Sci 12:358-367. https://doi. org/10.1016/j.tplants.2007.06.012

Sommer H, Beltrán JP, Huijser P et al (1990) Deficiens, a homeotic gene involved in the control of flower morphogenesis in Antirrhinum majus: the protein shows homology to transcription factors. EMBO J 9:605-613. https://doi.org/10.1002/j.1460-2075.1990. tb08152.x

Song C, Liu Y, Song A et al (2018) The Chrysanthemum nankingense genome provides insights into the evolution and diversification of chrysanthemum flowers and medicinal traits. Mol Plant 11:14821491. https://doi.org/10.1016/j.molp.2018.10.003

Su S, Xiao W, Guo W et al (2017) The CYCLOIDEA-RADIALIS module regulates petal shape and pigmentation, leading to bilateral corolla symmetry in Torenia fournieri (Linderniaceae). New Phytol 215:1582-1593. https://doi.org/10.1111/nph.14673

Subburaj S, Chung SJ, Lee C et al (2016) Site-directed mutagenesis in Petunia $\mathrm{x}$ hybrida protoplast system using direct delivery of purified recombinant Cas9 ribonucleoproteins. Plant Cell Rep 35:1535-1544. https://doi.org/10.1007/s00299-016-1937-7

Sun L, Kao TH (2018) CRISPR/Cas9-mediated knockout of PiSSK1 reveals essential role of S-locus F-box protein-containing SCF complexes in recognition of non-self S-RNases during crosscompatible pollination in self-incompatible Petunia inflata. Plant Reprod 31:129-143. https://doi.org/10.1007/s00497-017-0314-1

Sun W, Meng X, Liang L et al (2015) Molecular and biochemical analysis of chalcone synthase from Freesia hybrid in flavonoid biosynthetic pathway. PLoS ONE 10:e0119054. https://doi. org/10.1371/journal.pone.0119054

Svitashev S, Schwartz C, Lenderts B et al (2016) Genome editing in maize directed by CRISPR-Cas9 ribonucleoprotein complexes. Nat Commun 7:13274. https://doi.org/10.1038/ncomms13274

Tanaka Y, Brugliera F, Chandler S (2009) Recent progress of flower colour modification by biotechnology. Int J Mol Sci 10:5350 5369. https://doi.org/10.3390/ijms10125350

Tanaka Y, Oshima Y, Yamamura T et al (2013) Multi-petal cyclamen flowers produced by AGAMOUS chimeric repressor expression. Sci Rep 3:2641. https://doi.org/10.1038/srep02641

Tanase K, Nishitani C, Hirakawa H et al (2012) Transcriptome analysis of carnation (Dianthus caryophyllus L.) based on next-generation sequencing technology. BMC Genomics 13:1-11. https://doi. org/10.1186/1471-2164-13-292

Tang DQ, Sun Y, Li X et al (2018) De novo sequencing of the Freesia hybrida petal transcriptome to discover putative anthocyanin biosynthetic genes and develop EST-SSR markers. Acta Physiol Plant 40:168. https://doi.org/10.1007/s11738-018-2739-z

Tang X, Liang M, Han J et al (2020) Ectopic expression of LoSVP, a MADS-domain transcription factor from lily, leads to delayed flowering in transgenic Arabidopsis. Plant Cell Rep 39:289-298. https://doi.org/10.1007/s00299-019-02491-1

Theißen G, Saedler H (2001) Floral quartets. Nature 409:469-471. https://doi.org/10.1038/35054172

Theißen G, Melzer R, Rümpler F (2016) MADS-domain transcription factors and the floral quartet model of flower development: linking plant development and evolution. Development 143:32593271. https://doi.org/10.1242/dev. 134080

Tholl D (2006) Terpene synthases and the regulation, diversity and biological roles of terpene metabolism. Curr Opin Plant Biol 9:297-304. https://doi.org/10.1016/j.pbi.2006.03.014

Tholl D (2015) Biosynthesis and biological functions of terpenoids in plants. Adv Biochem Eng Biotechnol 148:63-106. https://doi. org/10.1007/10_2014_295

Tong C-G, Wu F-H, Yuan Y-H et al (2020) High-efficiency CRISPR/ Cas-based editing of Phalaenopsis orchid MADS genes. Plant Biotechnol J 18:889-891. https://doi.org/10.1111/pbi.13264

Tornielli G, Koes R, Quattrocchio F (2009) The genetics of flower color. In: Gerats T, Strommer J (eds) Petunia. Springer, New
York, NY, pp 269-299. https://doi.org/10.1007/978-0-38784796-2_13

Turck F, Fornara F, Coupland G (2008) Regulation and identity of florigen: FLOWERING LOCUS T moves center stage. Annu Rev Plant Biol 59:573-594. https://doi.org/10.1146/annur ev.arplant.59.032607.092755

Vainstein A, Lewinsohn E, Pichersky E, Weiss D (2001) Floral fragrance. New inroads into an old commodity. Plant Physiol 127:1383-1389. https://doi.org/10.1104/pp.010706

van der Kooi CJ, Stavenga DG (2019) Vividly coloured poppy flowers due to dense pigmentation and strong scattering in thin petals. J Comp Physiol A 205:363-372. https://doi.org/10.1007/ s00359-018-01313-1

van Dijk ADJ, Molenaar J (2017) Floral pathway integrator gene expression mediates gradual transmission of environmental and endogenous cues to flowering time. PeerJ 2017:1-18. https ://doi.org/10.7717/peerj.3197

Wan H, Yu C, Han Y, Guo X, Luo L, Pan H, Zheng T, Wang J, Cheng T, Zhang Q (2019) Determination of flavonoids and carotenoids and their contributions to various colors of rose cultivars (Rosa spp.). Front Plant Sci 10:123. https://doi.org/10.3389/ fpls.2019.00123

Wang HP, Yan HJ, Zhang H et al (2012) Cloning and Expression Analysis of Eugenol Synthase Gene RcEGS1 in Rosa chinensis "pallida." Acta Hortic Sin 39:1387-1394

Wang Y, Cheng X, Shan Q et al (2014) Simultaneous editing of three homoeoalleles in hexaploid bread wheat confers heritable resistance to powdery mildew. Nat Biotechnol 32:947-951. https://doi.org/10.1038/nbt.2969

Wang L, Sun J, Ren L et al (2020) CmBBX8 accelerates flowering by targeting CmFTL1 directly in summer chrysanthemum. Plant Biotechnol J 18:1562-1572. https://doi.org/10.1111/pbi.13322

Watanabe K, Kobayashi A, Endo M et al (2017) CRISPR/Cas9mediated mutagenesis of the dihydroflavonol-4-reductase-B (DFR-B) locus in the Japanese morning glory Ipomoea (Pharbitis) nil. Sci Rep 7:10028. https://doi.org/10.1038/s4159 8-017-10715-1

Watanabe K, Oda-Yamamizo C, Sage-Ono K et al (2018) Alteration of flower colour in Ipomoea nil through CRISPR/Cas9-mediated mutagenesis of carotenoid cleavage dioxygenase 4 . Transgenic Res 27:25-38. https://doi.org/10.1007/s11248-017-0051-0

Wei Z, Arazi T, Hod N, Zohar M, Isaacson T, Doron-Faigenboim A, Reznik N, Yedidia I (2020) Transcriptome profiling of Ornithogalum dubium leaves and flowers to identify key carotenoid genes for CRISPR gene editing. Plants 9:540. https://doi. org/10.3390/plants9040540

Weigel D, Alvarez J, Smyth DR et al (1992) LEAFY controls floral meristem identity in Arabidopsis. Cell 69:843-859. https://doi. org/10.1016/0092-8674(92)90295-n

Wellmann F, Griesser M, Schwab W et al (2006) Anthocyanidin synthase from Gerbera hybrida catalyzes the conversion of (+)-catechin to cyanidin and a novel procyanidin. FEBS Lett 580:16421648. https://doi.org/10.1016/j.febslet.2006.02.004

Wells RS, Adal AM, Bauer L et al (2020) Cloning and functional characterization of a floral repressor gene from Lavandula angustifolia. Planta 251:41. https://doi.org/10.1007/s00425-019-03333-w

Woo JW, Kim J, Kwon SI, Corvalán C, Cho SW, Kim H, Kim SG et al (2015) DNA-free genome editing in plants with preassembled CRISPR-Cas9 ribonucleoproteins. Nat Biotechnol 33:11621164. https://doi.org/10.1038/nbt.3389

Xiang L, Milc JA, Pecchioni N, Chen LQ (2007) Genetic aspects of floral fragrance in plants. Biochem 72:351-358. https://doi. org/10.1134/S0006297907040013

Xu Q, Wang S, Hong H, Zhou Y (2019) Transcriptomic profiling of the flower scent biosynthesis pathway of Cymbidium faberi Rolfe and functional characterization of its jasmonic acid carboxyl 
methyltransferase gene. BMC Genomics 20:125. https://doi. org/10.1186/s12864-019-5501-z

Xu J, Kang B-C, Naing AH et al (2020) CRISPR/Cas9-mediated editing of 1-aminocyclopropane-1-carboxylate oxidase1 enhances Petunia flower longevity. Plant Biotechnol J 18:287-297. https ://doi.org/10.1111/pbi.13197

Yagi M (2015) Recent progress in genomic analysis of ornamental plants, with a focus on carnation. Hort J 84:3-13. https://doi. org/10.2503/hortj.MI-IR01

Yagi M (2018) Recent progress in whole genome sequencing, highdensity linkage maps, and genomic databases of ornamental plants. Breed Sci 68:62-70. https://doi.org/10.1270/jsbbs.17080

Yagi M, Kosugi S, Hirakawa $\mathrm{H}$ et al (2014) Sequence analysis of the genome of carnation (Dianthus caryophyllus L.). DNA Res 21:231-241. https://doi.org/10.1093/dnares/dst053

Yamagishi M (2016) A novel R2R3-MYB transcription factor regulates light-mediated floral and vegetative anthocyanin pigmentation patterns in Lilium regale. Mol Breed 36:3. https://doi. org/10.1007/s11032-015-0426-y

Yan H, Zhang H, Chen M et al (2014) Transcriptome and gene expression analysis during flower blooming in Rosa chinensis "Pallida." Gene 540:96-103. https://doi.org/10.1016/j.gene.2014.02.008

Yan L, Wang X, Liu H et al (2015) The genome of Dendrobium officinale illuminates the biology of the important traditional Chinese orchid herb. Mol Plant 8:922-934. https://doi.org/10.1016/j. molp.2014.12.011

Yan H, Baudino S, Caissard J-C et al (2018) Functional characterization of the eugenol synthase gene (RcEGS1) in rose. Plant Physiol Biochem PPB 129:21-26. https://doi.org/10.1016/j.plaph y.2018.05.015

Yan R, Wang Z, Ren Y et al (2019) Establishment of efficient genetic transformation systems and application of CRISPR/Cas9 genome editing technology in Lilium pumilum DC. Fisch. and Lilium longiflorum White Heaven. Int J Mol Sci 20:2920. https://doi. org/10.3390/ijms20122920
Yanofsky MF, Ma H, Bowman JL et al (1990) The protein encoded by the Arabidopsis homeotic gene Agamous resembles transcription factors. Nature 346:35-39. https://doi.org/10.1038/346035a0

Zhang B, Yang X, Yang C et al (2016) Exploiting the CRISPR/Cas9 system for targeted genome mutagenesis in petunia. Sci Rep 6:20315. https://doi.org/10.1038/srep20315

Zhang GQ, Xu Q, Bian C et al (2016) The Dendrobium catenatum Lindl. genome sequence provides insights into polysaccharide synthase, floral development and adaptive evolution. Sci Rep 6:1-10. https://doi.org/10.1038/srep19029

Zhang Y, Liang Z, Zong Y et al (2016) Efficient and transgenefree genome editing in wheat through transient expression of CRISPR/Cas9 DNA or RNA. Nat Commun 7:12617. https://doi. org/10.1038/ncomms 12617

Zhang Y, Massel K, Godwin ID et al (2018) Applications and potential of genome editing in crop improvement. Genome Biol 19:210. https://doi.org/10.1186/s13059-018-1586

Zhang R, Fu X, Zhao C et al (2020) Identification of the key regulatory genes involved in elaborate petal development and specialized character formation in Nigella damascena (Ranunculaceae). Plant Cell 32:3095-3112. https://doi.org/10.1105/tpc.20.00330

Zhao D, Tao J, Han C, Ge J (2012) Flower color diversity revealed by differential expression of flavonoid biosynthetic genes and flavonoid accumulation in herbaceous peony (Paeonia lactiflora Pall.). Mol Biol Rep 39:11263-11275. https://doi.org/10.1007/ s11033-012-2036-7

Publisher's Note Springer Nature remains neutral with regard to jurisdictional claims in published maps and institutional affiliations. 